\title{
Therapeutic Screening of Herbal Remedies for the Management of Diabetes
}

\author{
Mahmoud Balbaa ${ }^{1, *(\mathbb{D}}$, Marwa El-Zeftawy ${ }^{2} \mathbb{D}$ and Shaymaa A. Abdulmalek ${ }^{1,3}$ \\ 1 Department of Biochemistry, Faculty of Science, Alexandria University, Alexandria 21511, Egypt; \\ shimaa_salamy@yahoo.com \\ 2 Biochemistry Department, Faculty of Veterinary Medicine, New Valley University, New Valley 72511, Egypt; \\ marwa@vet.nvu.edu.eg \\ 3 Center of Excellency for Preclinical Study (CE-PCS), Pharmaceutical and Fermentation Industries \\ Development Centre, The City of Scientific Research and Technological Applications, Alexandria 21511, Egypt \\ * Correspondence: mahmoud.balbaa@alexu.edu.eg; Fax: +20-3-3911794
}

check for

updates

Citation: Balbaa, M.; El-Zeftawy, M.; Abdulmalek, S.A. Therapeutic Screening of Herbal Remedies for the Management of Diabetes. Molecules 2021, 26, 6836. https://doi.org/ $10.3390 /$ molecules 26226836

Academic Editor: Guglielmina Froldi

Received: 23 October 2021

Accepted: 10 November 2021

Published: 12 November 2021

Publisher's Note: MDPI stays neutral with regard to jurisdictional claims in published maps and institutional affiliations.

Copyright: (c) 2021 by the authors. Licensee MDPI, Basel, Switzerland. This article is an open access article distributed under the terms and conditions of the Creative Commons Attribution (CC BY) license (https:// creativecommons.org/licenses/by/ $4.0 /)$.

\begin{abstract}
The study of diabetes mellitus (DM) patterns illustrates increasingly important facts. Most importantly, they include oxidative stress, inflammation, and cellular death. Up to now, there is a shortage of drug therapies for DM, and the discovery and the development of novel therapeutics for this disease are crucial. Medicinal plants are being used more and more as an alternative and natural cure for the disease. Consequently, the objective of this review was to examine the latest results on the effectiveness and protection of natural plants in the management of DM as adjuvant drugs for diabetes and its complex concomitant diseases.
\end{abstract}

Keywords: diabetes mellitus; Nigella sativa; curcumin; antidiabetic; hypoglycemic; insulin signal pathway

\section{Introduction}

Diabetes mellitus (DM) is a chronic endocrine disorder, and its adverse effects currently occupy a huge challenge for prevention and/or treatment [1]. It is categorized into three main forms, type I, type II, and recently type III DM [2]. The acquired form of DM is type II, as it chiefly results from insulin resistance syndrome [3]. The various fatal adverse effects of type II DM include diabetic foot [4], diabetic bone disease [5], diabetic neuropathy [6], and declined resistance to bacterial and viral infection via affecting the innate immunity [7]. The molecular mechanistic pathway of type II DM is attributed mainly to defects in the kinase molecular signaling pathways, PI3K, p38MAPK, PKA, and calmodulin kinase, which influence glucose metabolism and insulin action [8].

There are multiple synthetic antidiabetic therapeutic families such as sodium-glucose co-transporter-2 inhibitors [9], dipeptidyl peptidase-4 inhibitors [10], glucagon-like peptide 1 analogs [11], sulfonylureas [12], thiazolidinediones [13], and biguanides [14]. However, for nearly 20 years, the new science of natural therapy has been highlighted to minimize some chronic diseases including type II DM [15]. The active ingredients in natural therapy may have antidiabetic activity, e.g., nonflavonoid polyphenols such as curcumin, tannins, lignans, and resveratrol [16] or flavonoids such as anthocyanins, epigallocatechin gallate, quercetin, naringin, rutin, and kaempferol [17].

In brief, most polyphenols and flavonoids exhibit their antidiabetic influence via improving the glucose control and insulin sensitivity [16], inhibiting oxidative stress [17], reducing inflammatory cytokine levels [18], inhibiting $\alpha$-amylase and $\alpha$-glucosidase activity [19], and increasing tyrosine phosphorylation of insulin receptor (IR) [20].

\section{Diabetes Mellitus \\ 2.1. Prevalence, Types, Symptoms, Pathophysiology, and Molecular Mechanism of DM}

DM has received huge interest from most scientists as it is an international major public health threat. It is termed the silent killer, and it is predicted that, by the year 2030, 
the number of diabetic individuals will reach 578 million (700 million in 2045) [21]. DM is a chronic metabolic disorder, and there are two identified types, insulin-dependent DM (IDDM) and noninsulin-dependent DM (NIDDM). IDDM is an autoimmune disease caused as a result of the destruction of $\beta$-cells of the islets of Langerhans in the pancreas [22]. On the other hand, NIDDM occurs due to stress factors, obesity, and hormonal imbalance in which there is an overproduction of both insulin and amylin hormones from $\beta$-cells of the islets of Langerhans $[23,24]$, as well as a reduction in adiponectin, calcium $\left(\mathrm{Ca}^{2+}\right)$, and 25-hydroxyl vitamin D [25]. In recent years, Alzheimer's disease was designated type III DM [26], and it is usually marked by amyloid- $\beta$ plaques and phosphorylated-tau protein accumulation in the hippocampus of the brain [27]. Other types of DM may be temporary, such as gestational DM, which occurs in the second or third trimester of pregnancy in females and typically disappears after parturition [28]. Furthermore, in some conditions, DM results from complete or partial dissection of the pancreas as a consequence of some diseases related to the pancreas, such as tumors or severe inflammation [29].

In summary, the inability of pancreatic $\beta$-cells to produce insulin in IDDM [30] or insulin resistance [31] is implicated in the failure of insulin to perform its function, leading to hyperglycemia, polyuria, weight loss or increase, polydipsia, delayed wound healing, and blurred vision [32]. Hyperglycemia itself leads to an increase in the production of advanced glycation end-products (AGEs) and their receptors [33]. In this regard, especially in NIDDM, this is accompanied by the promotion of free radicals in the mitochondrial matrix that damage multiple biomolecules of the cell such as deoxyribonucleic acid (DNA), lipids, and proteins [34]. Consequently, this increases susceptibility to chronic inflammation and apoptosis, as well as impairs the function of various body organs [35].

On the other hand, AGEs and their receptors increase the activity of nicotinamide adenine dinucleotide phosphate (NADPH) oxidases and their messenger ribonucleic acid (mRNA), as well as arachidonic acid pathways [36]. The interaction of AGEs with the receptors of advanced glycation end-products (RAGEs) leads to the stimulation of some cell signal transduction pathways such as protein kinase C (PKC), phosphatidylinositol 3-kinase/protein kinase B (PI3K/Akt) [37], p38 mitogen-activated protein kinase (p38 MAPK) [38], extracellular signal-related kinases (ERK) [39], RhoA/Rho-kinase which activates many downstream kinases and mediates $\mathrm{Ca}^{2+}$ sensitization [40], Janus kinase/signal transducer and activator of transcription (JAK/STAT), and suppressor of the cytokine signaling 3 (SOCS3) [41]. Furthermore, there is dysregulation of $5^{\prime}$-adenosine monophosphate-activated protein kinase (5'-AMPK) activity via inhibition of gluconeogenesis genes [42], downregulation of glucose transporter-4 (GLUT-4) [43], stimulation of lipogenesis through elevation of HMG CoA reductase activity [44], and initiation of mitochondrial axonal cell death [45]. The consequence of these activated signals are (i) an increase in the level of transcription factors including nuclear factor- $\mathrm{kB}$ (NF- $\mathrm{kB}$ ) [46] and early growth response-1 (Egr-1) protein, which is a vital zinc finger transcription factor [47], (ii) alteration of cell metabolism, and (iii) induction of inflammation, apoptosis, and proliferation by the NOD-like receptor protein-3 (NLRP-3) inflammasome [48]. Tumor necrosis factor-alpha (TNF- $\alpha$ ), monocyte chemoattractant protein-1 (MCP-1), interleukin-6 (IL-6), and interleukin-1 beta (IL-1 $\beta$ ) are among the cytokines produced [49]. These cytokines impair insulin signaling and peripheral glucose uptake and contribute to insulin resistance, lipolysis, and hepatic glucose production [50].

Moreover, hyperglycemia in NIDDM is a hazardous issue that disturbs the genetic expression responsible for insulin secretion, e.g., sirtuin-1 (Sirt-1) and glucose transporter-2 (GLUT-2), in $\beta$-cells [51]. It also activates the signaling pathway of insulin in adipose tissue and skeletal muscle, e.g., glucose transporter-4 (GLUT-4), which carries glucose from the cytoplasm to the membrane, and peroxisome proliferator-activated gamma receptor (PPAR- $\gamma$ ) [52], or in hepatic tissue, e.g., insulin receptor substrate-1 (IRS-1) serine/threonine/Akt-1 and phosphoenolpyruvate carboxykinase (PEPCK) [53]. The molecular mechanism of insulin resistance is illustrated in Figure 1. 


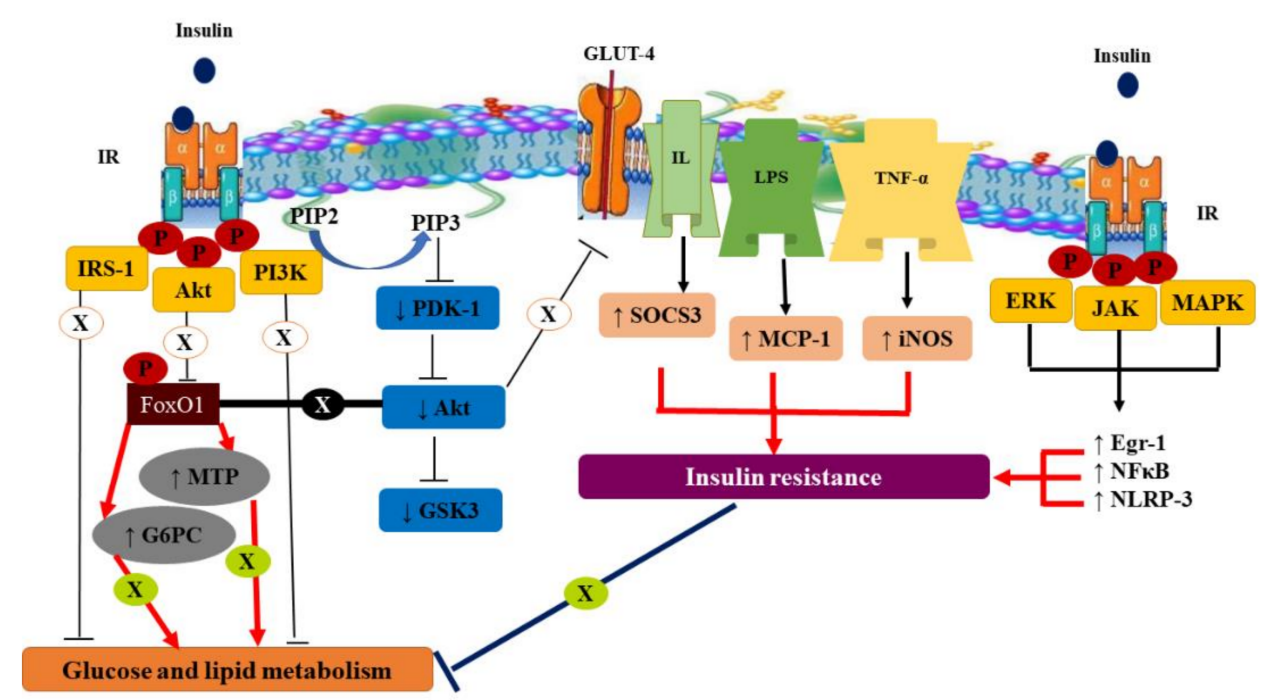

Figure 1. Molecular mechanism of insulin resistance. Akt: protein kinase B, IRS-1: insulin receptor substrate-1, PI3K: phosphatidyl inositol-3-kinase, PIP2: phosphatidylinositol 4,5-bisphosphate, PIP3: phosphatidylinositol 3,4,5-trisphosphate, PDK-1: phosphoinositide-dependent protein kinase 1, GSK3: glycogen synthase kinase 3, GLUT-4: glucose transporter-4, IL: interleukin, SOCS3: suppressor of the cytokine signaling, LPS: lipopolysaccharides, MCP-1: monocyte chemoattractant protein-1, TNF- $\alpha$ : tumor necrosis factor-alpha, iNOS: inducible nitric oxide synthase, ERK: extracellular signalrelated kinase, JAK: Janus kinase-2, MAPK: mitogen-activated protein kinase, Egr-1: early growth response-1, NF-кB: nuclear factor-kappa B, NLRP-3: NOD-like receptor protein-3, FoxO1: forkhead box O1, MTP: microsomal triacylglycerol transfer protein, G6PC: glucose-6-phosphatase catalytic subunit 1.

\subsection{Complications of $D M$}

Untreated DM harms the minute blood vessels of some organs such as the kidney, heart, eye, and nervous system [54]. Hence, diabetic nephropathy [55], cardiomyopathy [56], retinopathy [57], and diabetic foot infection [58] are well-known adverse outcomes. Furthermore, vagus nerve atrophy may occur as an outcome of neuronal, autoimmune damage, and oxidative stress [59]. DM is connected to various musculoskeletal ailments, such as joint stiffness, gouty arthritis, osteoarthritis, rheumatoid arthritis, and diabetic amyotrophy [60]. In some cases, the negative effects of DM have been linked to the gut, where there has been a decrease in butyrate-producing bacteria and an increase in opportunistic pathogens [61]. moreover, the incidence of cancer may be a consequence of DM in some late stages [62]. A decrease in the salivary flow and elements is also obvious in diabetic individuals [63]. Furthermore, diabetic ketoacidosis and hyperglycemic hyperosmolar syndrome are both considered dangerous DM risks due to insulin deficiency, which results in the formation of ketone bodies and the occurrence of metabolic acidosis [64]. In some diabetic individuals, low immunity is also documented to make them more vulnerable to invasive fungal infections, such as the filamentous fungus Syncephalastrum racemosum, that affect the gastrointestinal tract [65].

Moreover, in 2020, it was confirmed that diabetic patients are very likely to be infected with COVID-19 due to their immune impairment [66]. Normally, the angiotensin-2 conversion enzyme (ACE-2) is expressed in $\beta$-pancreatic cells, and the SARS-Cov-2 virus binds primarily to ACE-2, causing damage to $\beta$-pancreatic cells [67]. It should be noted that, by stimulating oxidation free radicals and hypoxia-inducible factor 1 alpha (HIF-1 $\alpha), \mathrm{DM}$ enhances the replication of the virus [68]. Certain NIDDM conditions in different tissues are shown in Figures 2 and 3. 


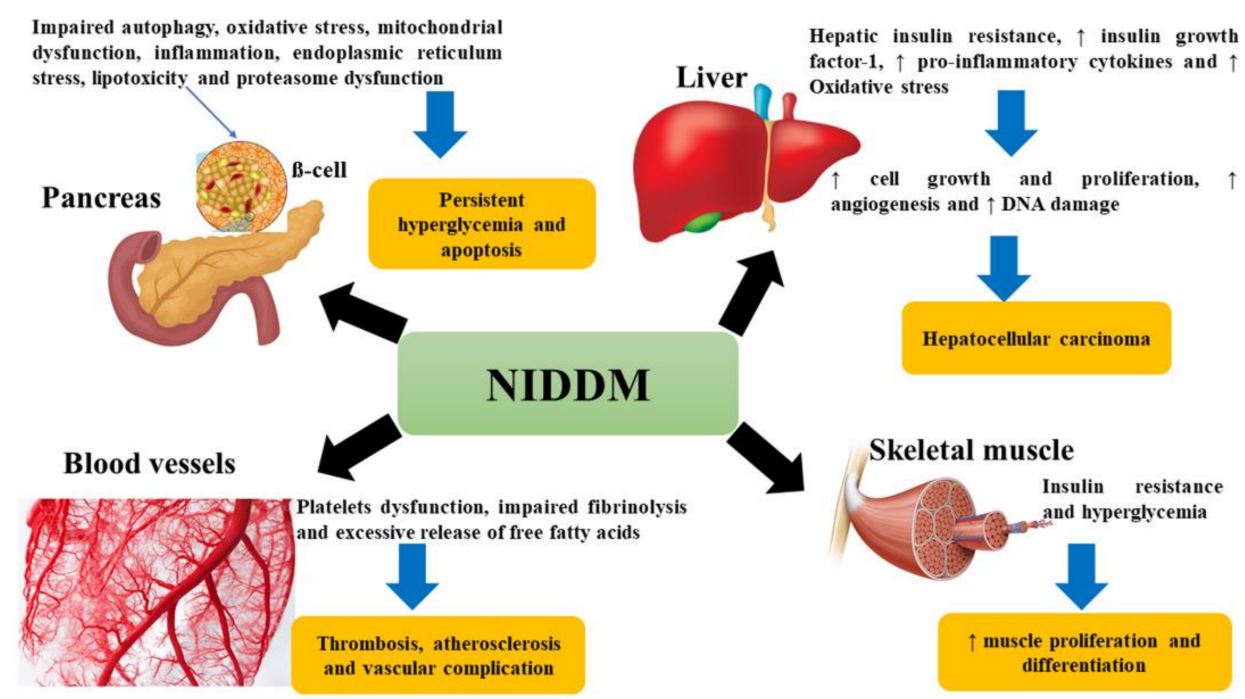

Figure 2. Effect of noninsulin-dependent diabetes mellitus (NIDDM) on liver, pancreas, blood vessels, and skeletal muscle. ER: endoplasmic reticulum, DNA: deoxyribonucleic acid.

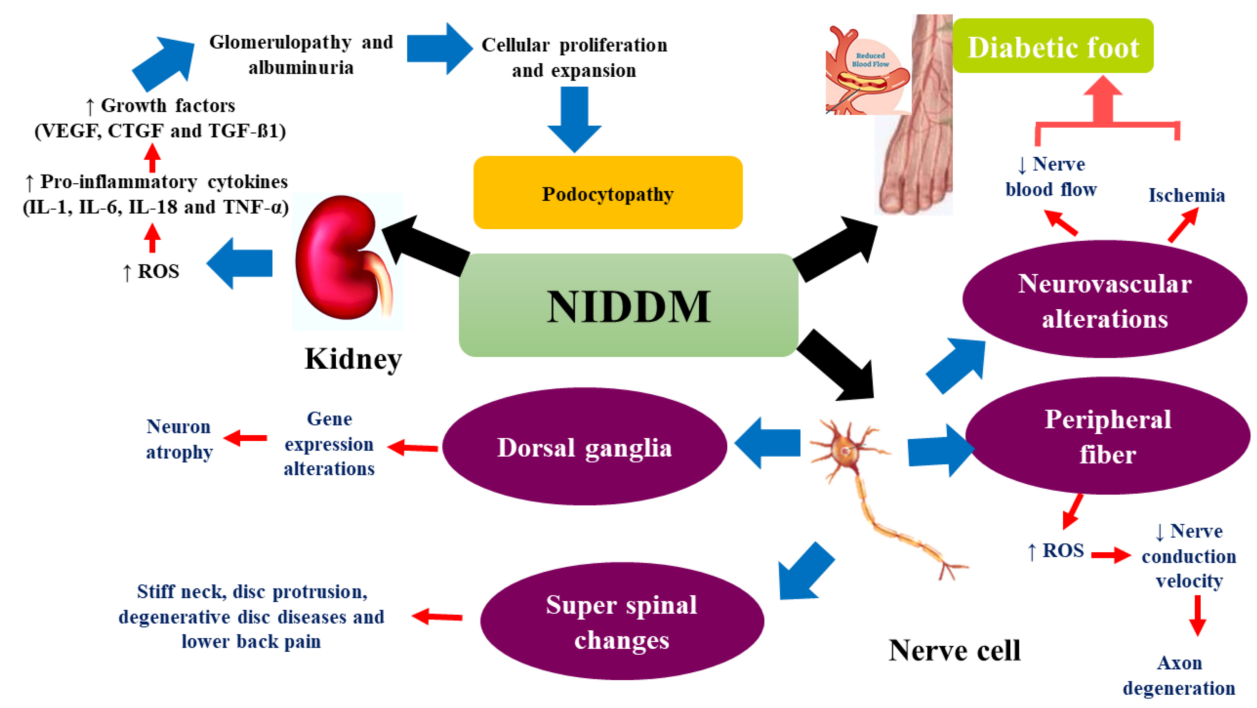

Figure 3. Effect of noninsulin-dependent diabetes mellitus (NIDDM) on kidney, nerve cell, and foot. VEGF: vascular endothelial growth factor, CTGF: connective tissue growth factor, TGF- $\beta 1$ : transforming growth factor-beta 1, IL-1: interleukin-1, IL-6: interleukin-6, IL-18: interleukin-18, TNF- $\alpha$ : tumor necrosis factor-alpha, ROS: reactive oxygen species.

\section{Natural Therapy: A Safe Tool for DM Management}

Today, due to their improved cost-effectiveness and avoidance of side-effects of certain drugs, medicinal plants may be used in the handling of DM. As shown in Figure 4, some herbal plants were found to improve hyperglycemia and insulin resistance via the AMPK signaling pathway.

\subsection{Nigella Sativa (NS)}

NS is often known as black cumin, belonging to the Ranunculaceae family, which grows extensively in many countries; it has many traditional uses as a spice and food preservative [69]. NS seeds have many biological functions, including carminative, stimulant, analgesic, antipyretic, and diuretic functions [70]. A complex blend of fatty acids, vitamins, pigments, and volatile components constitutes NS oil (NSO), which includes thymoquinone (TQ) and its associated compounds, thymol and dithymoquinone. It is 
important for the treatment of many diseases such as tumors, gastrointestinal disorders, cirrhosis, hepatitis, and chemical poisoning [71]. NSO also exhibited in vivo antidiabetic and neuroprotective effects in an animal model of experimental diabetes [72,73]. NS seed extract also had a beneficial effect on the liver [74]. NS regenerates $\beta$-cells of the pancreas during hyperglycemia as a consequence of its high polyphenol content, which enhances the metabolic process of carbohydrates and lipids [75] and its ability to hinder the upregulation of gluconeogenesis enzymes [76].

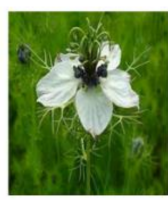

NS

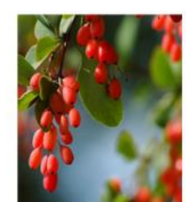

BER

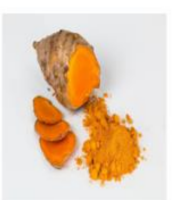

CUR

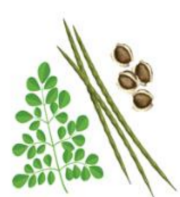

MO

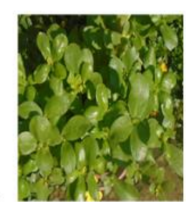

PO

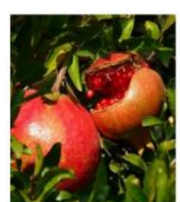

PG

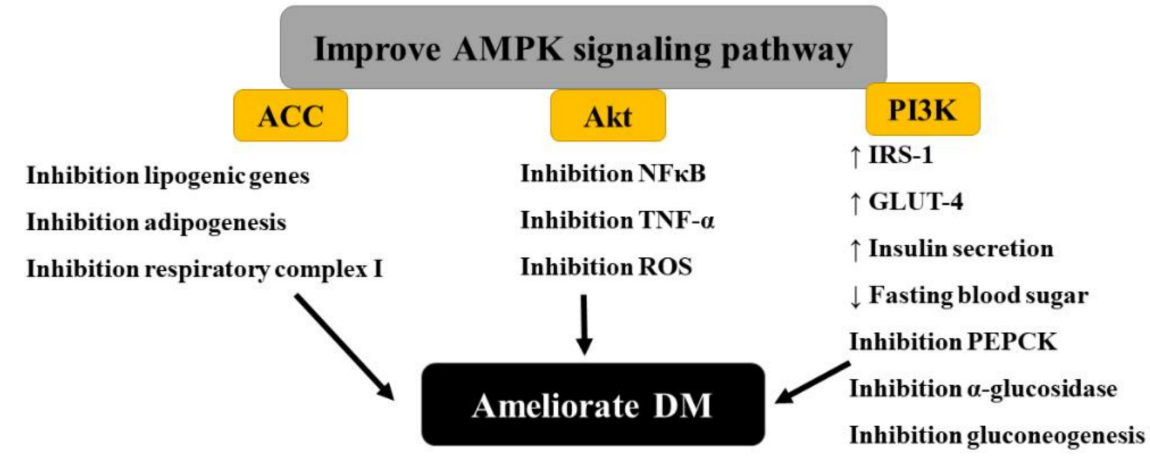

Figure 4. Effect of some natural plants on adenosine monophosphate-activated protein kinase (AMPK) signaling pathway. NS: Nigella sativa, BER: berberine, CUR: curcumin, MO: Moringa olifera, PO: Portulaca oleracea; PG: Punica granatum, ACC: acetyl CoA carboxylase, Akt: protein kinase B, NFKB: nuclear factor-kappa B, TNF- $\alpha$ : tumor necrosis factor-alpha, ROS: reactive oxygen species, PI3K: phosphatidyl inositol-3-kinase, IRS-1: insulin receptor substrate-1, GLUT-4: glucose transporter4, FBS: fasting blood sugar, PEPCK: phosphoenolpyruvate carboxykinase, $\alpha$-glucosidase: alphaglucosidase, DM: diabetes mellitus.

Several processes involving NSO itself or its main active ingredient, TQ, are responsible for the antidiabetic activity of NSO. Via stimulation of AMPK phosphorylation in hepatic and muscle tissues, NSO can increase insulin sensitivity [77]. Furthermore, NSO improves GLUT-4, insulin-like growth factor-1, and phosphatidyl inositol-3-kinase (PI3K) [78]. By inhibiting sodium-glucose co-transporters, NSO decreases glucose absorption from the intestine [79]. Another theory clarified that the decrease in the amount of glucose by NSO is due to its inhibitory effect on $\alpha$-glucosidase [80]. NSO increases PARP- $\gamma$ in the adipocyte and inhibits an enzyme that degrades insulin considered a cause of hyperglycemia [81]. Because of its unsaturated fatty-acid content and the downregulation of the 3-hydroxy-3-methylglutaryl-coenzyme reductase gene, which inhibits cholesterol oxidation and triacylglycerol lipoproteins, NSO affects hyperlipidemia caused by DM [82].

The oxidative stress present in DM is due to substantial production of the reduced form of nicotinamide adenine dinucleotide (NADH) that disrupts the equilibrium between $\mathrm{NADH}$ and its oxidized form $\mathrm{NAD}^{+}$, thus resulting in oxidative stress. Therefore, it is a redox imbalance disease [83]. Via the NADP-dependent redox cycle, TQ in NSO can re-oxidize NADH and, thus, decrease the NADH:NAD ${ }^{+}$ratio. The re-oxidation of NADH to $\mathrm{NAD}^{+}$by TQ stimulates glucose and fatty-acid oxidation, as well as Sirt-1-dependent pathways [84]. Moreover, $\mathrm{NAD}^{+}$activates Sirt-1, which is an $\mathrm{NAD}^{+}$-dependent histone deacetylase that plays a key role in controlling both carbohydrate and lipid metabolism, as well as the secretion of adiponectin and insulin, and that protects pancreatic $\beta$-cells from oxidative stress and inflammation by inhibiting NF-kB activity [85]. The anti-inflammatory effect of NS during DM is notably linked with its repressing influences on cyclooxygenase 
and 5-lipoxygenase pathways, reducing nitric oxide, MCP-1, and TNF- $\alpha$ production and inhibiting IL-1 $\beta$ and IL-6 [86]. Furthermore, NS disrupts some DM complications such as nephropathy through upregulation of vascular endothelial growth factor-A (VEGFA) and transforming growth factor- $\beta$ (TGF- $\beta 1$ ) [87]. The molecular mechanistic pathways of the antidiabetic effect of NS are reported in Figure 5.

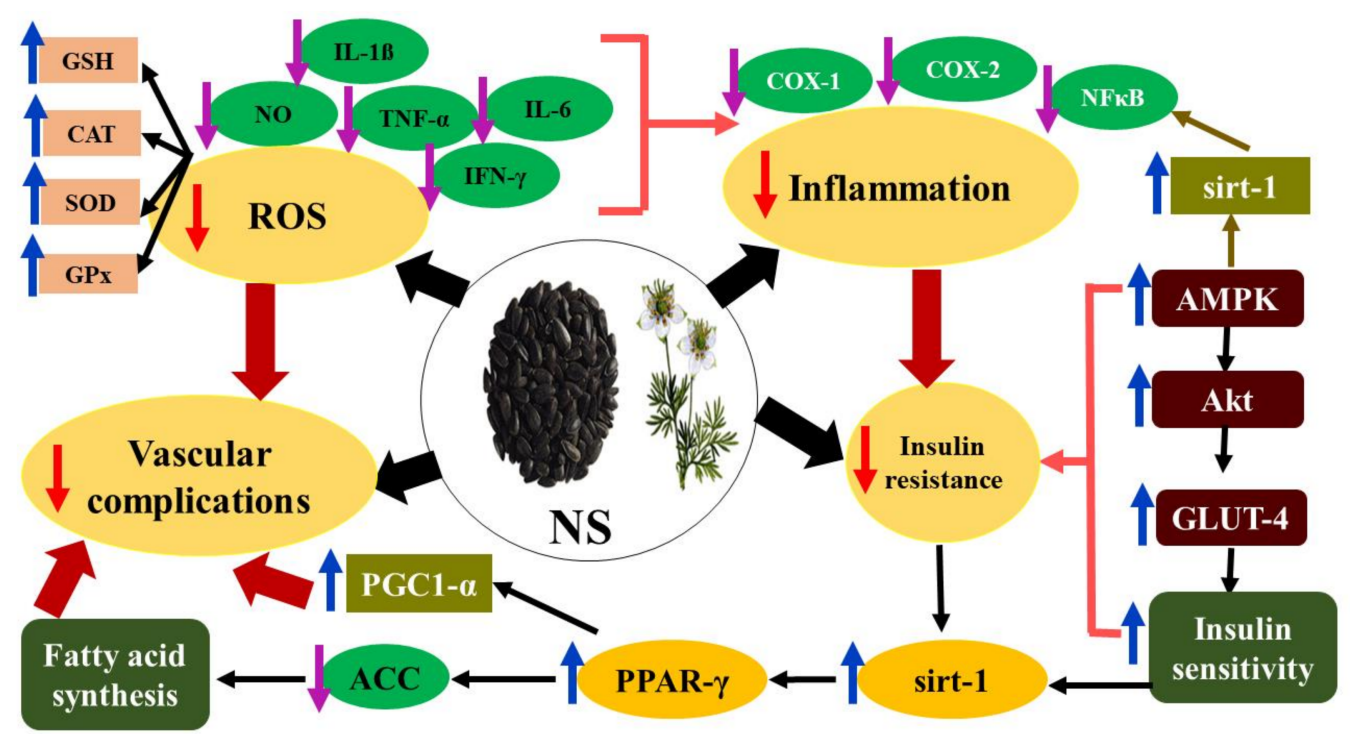

Figure 5. The molecular mechanistic pathways of antidiabetic effect of NS. GSH: reduced glutathione, CAT: catalase, SOD: superoxide dismutase, GPx: glutathione peroxidase, ROS: reactive oxygen species, NO: nitric oxide, IL-1 $\beta$ : interleukin-11 beta, TNF- $\alpha$ : tumor necrosis factor-alpha, IL-6: interleukin-6, IFN- $\gamma$ : interferon-gamma, COX-I: cyclooxygenase-I, COX-II: cyclooxygenase-II, NF- $\mathrm{B}$ : nuclear factor-kappa B, Sirt-1: Sirtuin-1, AMPK: adenosine monophosphate-activated protein kinase, Akt: protein kinase B, GLUT-4: glucose transporter-4, PPAR- $\gamma$ : peroxisome proliferator-activated receptor-gamma, ACC: acetyl CoA carboxylase, PGC1- $\alpha$ : peroxisome proliferator-activated receptor gamma coactivator 1-alpha.

\subsection{Berberine (BER)}

BER is a quaternary ammonium isoquinoline alkaloid, which is present in some plant families such as Berberidaceae, Papaveraceae, Ranunculaceae, Rutaceae, and Menispermaceae [88]. BER achieves notable effects in treating and/or preventing various metabolic factors such as DM, hyperlipidemia, obesity, liver dysfunction, and some diseases related to disorders in nucleic acid metabolism [89]. In this review, we focus on the antidiabetic targets of BER that have multiple pathways. BER promotes insulin secretion, glucose uptake, and glycolysis [90], and it can also improve glycogenesis as a consequence of the inactivation of glycogen synthase kinase enzyme [91]. On the other hand, it prevents gluconeogenesis due to the reduction in its key regulatory enzymes, glucose-6-phosphate dehydrogenase and PEPCK [92]. Furthermore, BER reduces insulin resistance by upregulating PKC-dependent IR expression [93]; by blocking mitochondrial respiratory complex I, the adenosine monophosphate/adenosine triphosphate (AMP/ATP) ratio increases, thereby stimulating AMPK [94]. Hence, activated AMPK regulates transcription of uncoupling protein 1 in white and brown adipose tissue [95] and helps the phosphorylation of acetyl-CoA carboxylase (ACC) and carnitine palmitoyltransferase I enzymes, causing a reduction in lipogenesis and an increase in fatty-acid oxidation [96]. Via retinol-binding protein-4 and phosphatase and tension homolog downregulation, as well as sirt-1 activation, BER has a hypoglycemic function, thus improving insulin resistance in skeletal muscles [97].

Another mechanism of BER antidiabetic influence is attributed to its ability to regulate both short-chain fatty acids and branched-chain amino acids [98], whereby it diminishes 
the butyric acid-producing bacteria that destroy the polysaccharides [99]. A previous study displayed the role of BER in preventing cholesterol absorption from the intestine through improving cholesterol-7 $\alpha$-hydroxylase and sterol 27-hydroxylase gene expression [100]. Moreover, BER provides a vigorous defense against insulin resistance via the normalization of protein tyrosine phosphatase 1-B [101] and PPAR- $\gamma /$ coactivator- $1 \alpha$ signaling pathways that enhance fatty-acid oxidation [102]. Additionally, it was illustrated that BER adjusts GLUT-4 translocation via AS160 phosphorylation as a consequence of AMPK activation in insulin-resistant cells [103].

During DM there is a relationship between inflammation and oxidative stress which leads to the creation of proinflammatory cytokines such as IL-6 and TNF- $\alpha$ [104]. It was reported that BER counteracts some inflammatory processes where it attenuates NADPH oxidase (NOX) that is responsible for reactive oxygen species (ROS) generation, thereby decreasing AGEs and increasing endothelial function in DM [105]. BER displayed a tendency to ameliorate the inflammation resulting from DM via various pathways, e.g., suppression of phosphorylated Toll-like receptor (TLR) and IkB kinase- $\beta$ (IKK- $\beta$ ) that is responsible for NF- KB activation; thus, BER interferes with the serine phosphorylation of IRS and diminishes insulin resistance [106]. Moreover, BER activates P38 that inhibits nuclear factor erythroid-2 related factor-2 (Nrf-2) and heme oxygenase-1 (HO-1) enzyme blockage, leading to proinflammatory cytokine production [107]. In addition, BER inhibits activator protein-1 (AP-1) and, thus, suppresses the production of cyclooxygenase-2 (COX-2) and MCP1 [108]. It was stated that BER alleviates some DM complications due to its capability of attenuating DNA necrosis in different affected tissues and enhancing the cell viability [109]. It was shown that BER protects the lens in diabetic eyes from cataract incidence by improving the polyol pathway through inactivation of the aldose reductase enzyme responsible for the conversion of glucose into sorbitol that degenerates the lens fiber [110]. Figure 6 shows some of the hypoglycemic mechanisms of BER mentioned above.

\subsection{Curcumin (CUR)}

CUR, a polyphenolic compound derived from the turmeric rhizomes of Curcuma longa, is commercially used as a spice and food preservative agent [111]. It also has beneficial effects on several chronic disease states linked with inflammation and oxidative stress, as observed in DM and cancer [112]. Recently, it was reported that CUR inhibits the COVID-19 protease enzyme [113]. One proposed mechanism of CUR ameliorating DM is related to its antihyperlipidemic activity via suppression of fatty-acid synthase, carnitine palmitoyltransferase 1, 3-hydroxy-3-methyl glutaryl coenzyme A reductase, and acyl-CoA cholesterol acyltransferase enzymes [114]. Moreover, CUR can diminish lipogenesis in insulin resistance syndrome, which is attributed to the inactivation of two transcription lipogenic factors: sterol regulatory element-binding protein-1-c (SREBP-1c) and carbohydrate response element-binding protein [115]. Furthermore, CUR was able to correct elevated protein-tyrosine phosphatase 1-B resulting from insulin resistance syndrome [116], leading to an improvement of the phosphorylation of insulin receptor substrate-1 (IRS-1) and JAK-2 [117], as well as suppression of STAT3 and SOCS3 [118]. CUR also stimulates Akt and ERK 1/2 [119], as well as alters the phosphatidylinositol 3-hydroxy kinase/ Akt signaling pathway [120].

Moreover, the anti-inflammatory properties of CUR are attributed to its ability to inhibit macrophage infiltration and migration into metabolic organs, as well as decline some transcription inflammatory markers, including NF- $\kappa B$ and proinflammatory cytokines such as TNF- $\alpha$, IL-1 $\beta$, TLR-4, and C-reactive protein [121]. Other inflammatory indicators such as cyclooxygenase, phospholipases, and MCP-1 can be decreased in DM after the therapeutic use of CUR [122]. CUR has been found to play a role in the diabetic effect by obstructing TLR-4 activation and modifying caveolin-1 phosphorylation in diabetic patients [123].

Another effect of CUR is that it maintains mitochondrial destruction and disruption while improving mitochondrial membrane potential and biogenesis [124]. The importance of mitochondria is reflected by their role in mediating metabolic pathways and preserving 
cellular functions such as ion hemostasis, antioxidant defense, fatty-acid oxidation, aminoacid biosynthesis, and energy production [125]. CUR potentiates the mitochondrial activity by enhancing (i) cytochrome c protein level, which has a vital function in mitochondrial oxidative phosphorylation, and (ii) mitochondrial carnitine palmitoyltransferase 1 enzyme, which transports long-chain fatty acids into the mitochondria for $\beta$-oxidation [126].

CUR diminishes hypoxia-induced cell injury and HIF-1 $\alpha$, which is an oxygen-dependent conversion activator and is closely related to oxidative stress specific to diabetic cardiomyopathy [127]. CUR also plays a role in increasing wound healing in experimental diabetic rats by enhancing the expression of certain granulation tissue growth factors such as vascular endothelial growth factor (VEGF), stromal cell-derived factor-1 alpha (SDF-1 $\alpha$ ), and tumor growth factor- $\beta 1$. Endothelial nitric oxide synthase was also enhanced [128]. CUR treatment was able to improve insulin sensitivity and diabetic cardiac complications via upregulation of some thermogenic genes such as uncoupling proteins 1, 2, and 3 [129], which are mitochondrial anion carriers, and it can adjust the heart's energy metabolism and protect it against ROS by modulating mitochondrial respiration [130]. CUR treatment leads to a decrease in the accretion of S-phase kinase-associated protein 2 (S-phase Skp2) and enhances p27 protein accumulation in the pancreatic cancer cell, resulting in a significant amelioration of diabetic nephropathy [131,132]. The potential hypoglycemic role of CUR is shown in Figure 7.

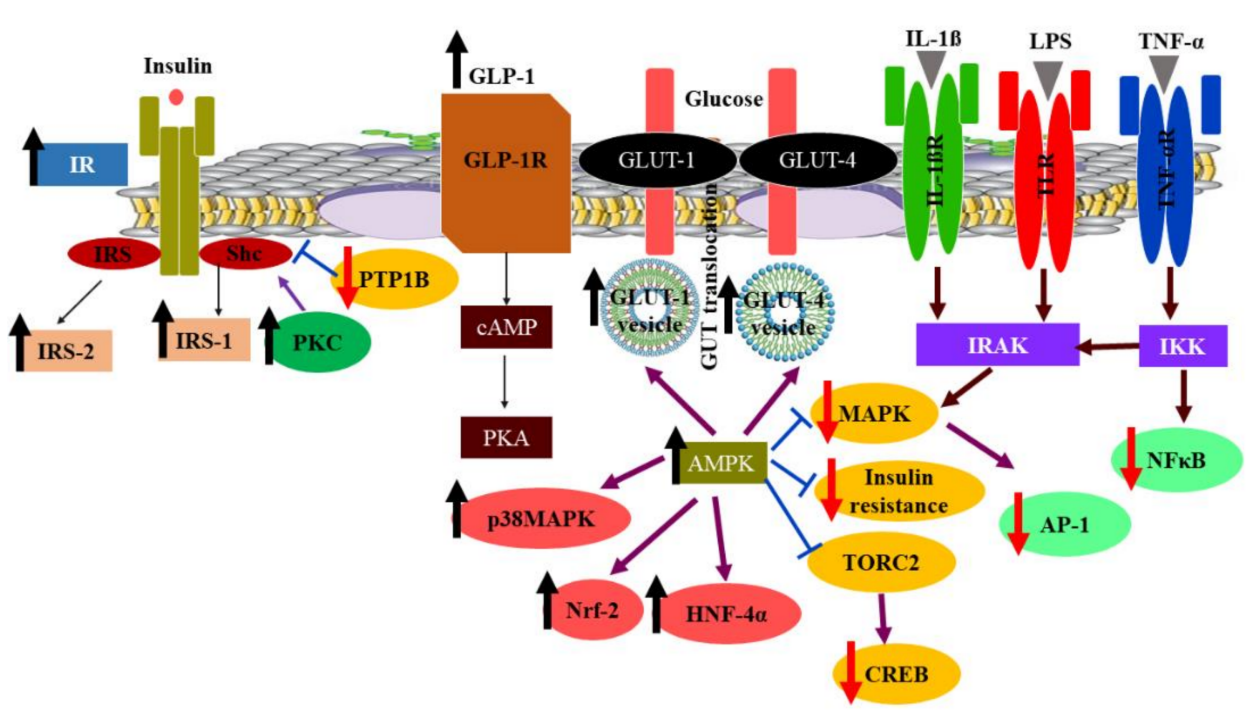

Figure 6. Molecular pathways of BER in ameliorating NIDDM. InsR: insulin receptor, IRS: insulin receptor substrate, IRS-1: insulin receptor substrate-1, IRS-2: insulin receptor substrate-2, Shc: mammalian Shc locus encoding three protein variants with molecular mass of 46, 52, and $66 \mathrm{kDa}$ and identical modular structure, PKC: protein kinase C, PTP1B: protein tyrosine phosphatase 1B, GLP-1: glucagon-like peptide-1, GLP-IR: glucagon-like peptide-1 receptor, cAMP: cyclic adenosine monophosphate, PKA: protein kinase A, GLUT-1: glucose transporter-1, GLUT-4: glucose transporter-4, GLUT: glucose transporter, AMPK: adenosine monophosphate-activated protein kinase, p38 MAPK: p38 mitogenactivated protein kinase, Nrf2: protein regulating the expression of antioxidant proteins that protect against oxidative damage triggered by injury and inflammation, HNF- $4 \alpha$ : hepatocyte nuclear factor-4 alpha, MAPK: mitogen-activated protein kinase, TORC2: target of rapamycin 2 kinase, CREB: cAMP response element-binding protein, IL-1 $\beta$ : interleukin-1 beta, IL-1 $\beta$ R: interleukin-1 beta receptor, LPS: lipopolysaccharides, TLR: Toll-like receptor, IRAK: interleukin-1 receptor-associated kinase, AP-1: activator protein-1, TNF- $\alpha$ : tumor necrosis factor-alpha, TNF- $\alpha$ R: tumor necrosis factor-alpha receptor, IKK: IkB kinase (a cytokine-activated protein kinase complex), NF- $k B$ : Nuclear factor kappa B. 


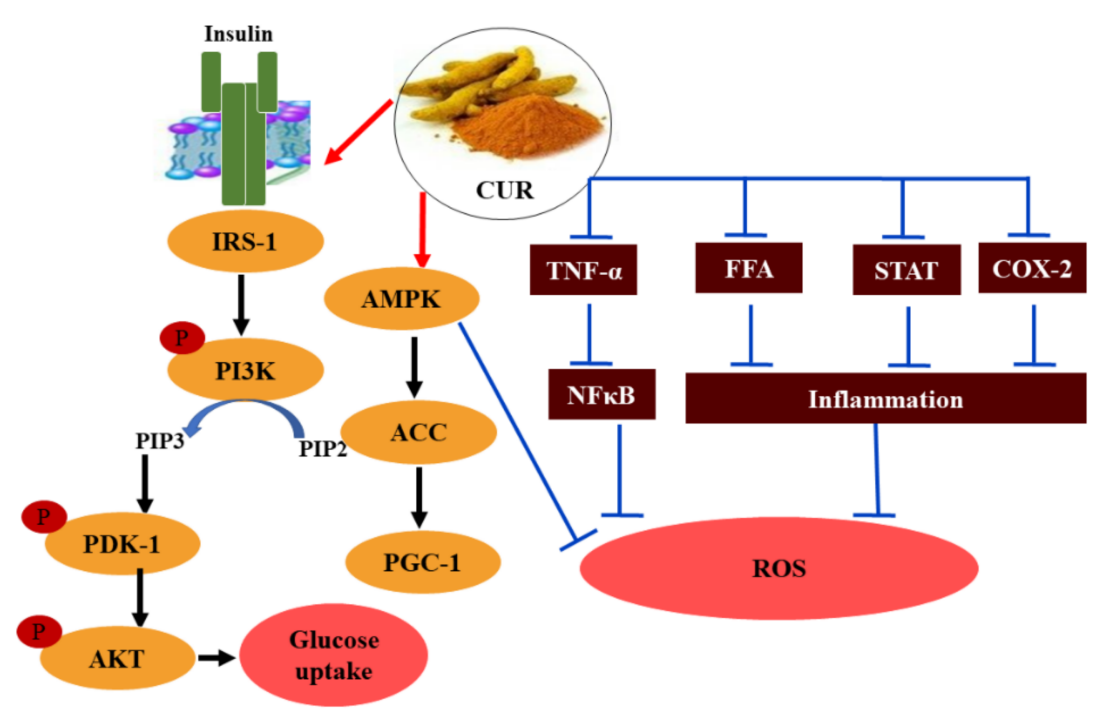

Figure 7. Mechanisms of the potential antidiabetic effect of CUR. IRS-1: insulin receptor substrate-1, PI3K: phosphatidyl inositol-3-kinase, PIP2: phosphatidylinositol 4,5-bisphosphate, PIP3: phosphatidylinositol 3,4,5-trisphosphate, PDKI: phosphoinositide-dependent protein kinase 1, Akt: protein kinase B, AMPK: adenosine monophosphate-activated protein kinase, ACC: acetyl CoA carboxylase, PGC-1: peroxisome proliferator-activated receptor-gamma coactivator, TNF- $\alpha$ : tumor necrosis factor-alpha, NF-kB: nuclear factor-kappa B, FFA: free fatty acids, STAT: Signal transducer and activator of transcription, COX-2: cyclooxygenase-2, ROS: reactive oxygen species.

\subsection{Moringa Oleifera (MO)}

$\mathrm{MO}$ is a persistent deciduous tropical plant belonging to the genus Moringa of the family Moringaceae; it is described as the marvel tree because all its parts have multiple uses in medicinal, industrial, agricultural, or functional foods [133]. The flowers, pods, leaves, and seeds of $\mathrm{MO}$ are regarded as food sources that contain growth promoters, as they are characterized by a high content of vitamins, minerals, and proteins [134]. From the pharmacological view, it possesses anticancer, antidiabetic, anti-inflammatory, antimicrobial, antihypertensive, and antiulcer purposes [135]. Several mechanisms contribute to the hypoglycemic curative effect of MO derived from its active constituents, particularly three classes of phytochemicals, phenolic acids (chlorogenic acid), flavonoids (quercetin and kaempferol), and glucosinolates, which have good antioxidant scavenging activity toward ROS [136]. In this regard, certain phytochemicals in MO such as quercetin and terpenoid were found to enhance glucokinase enzyme activity and pancreatic $\beta$-cells, respectively, thereby minimizing insulin resistance [137]. Due to the presence of isothiocyanates as one of its active ingredients, $\mathrm{MO}$ can inhibit both gluconeogenesis and glycogenolysis in the liver, as well as the absorption of glucose into adipose tissue and muscles [138]. $\mathrm{MO}$ also battles insulin resistance in the muscle via GLUT-4 activation, which leads to an improvement in the Akt signaling pathway [139]. On the one hand, via triggering Sirt-1, which interacts with and deacetylates peroxisome proliferator-activated receptor- 1 alpha (PPAR-1 $\alpha$ ), the presence of niazirin, a phenolic glycoside in MO seeds, increases the phosphorylation of AMPK $\alpha$ [140]. It minimizes the levels of forkhead box protein O1 (FOXO1) and hepatocyte nuclear factor 4 alpha (HNF-4 $\alpha$ ), allowing peroxisome-proliferator activated receptor- $\alpha$ (PPAR- $1 \alpha$ ) to obstruct the gluconeogenesis process. Moreover, it regulates the PKC-zeta/Nox4/ROS signaling pathway that potentially decreases the oxidative stress produced in DM [141].

Furthermore, MO improves fatty-acid oxidation via the AMPK/ACC and/or PPAR$\alpha$ pathways; however, it hinders triacylglycerol and cholesterol biosynthesis through sterol regulatory element-binding protein-1 (SREBP-1) regulation [142]. MO is closely related to the downregulation of $\alpha$-glucosidase, pancreatic lipase, and lipoprotein lipase 
enzymes, which are crucial rate-restrictive enzymes obligatory for the hydrolysis of dietary carbohydrates and fats during carbohydrate and lipid metabolism [143].

\subsection{Portulaca Oleracea (PO)}

PO belongs to the Portulacaceae family. It is an annual succulent herb that grows in warm climates and is dispersed as turfgrass weed or field crop [144]. It exhibits good nutritional quality due to its high content of $\alpha$-linolenic acid, ascorbic acid, $\beta$-carotene, and vitamin B complex [145]. Furthermore, it reveals a broad range of biological activities such as antiaging, antiulcerogenic, antimicrobial, antidiabetic, anticancer, anti-inflammatory, antiseptic, and neuroprotective properties, in addition to improving the immune system [146]. Here, we present several hypotheses underlying the hypoglycemic influence of PO. One such theoretical effect of $\mathrm{PO}$ is correlated with the promotion of insulin production in pancreatic cells via closure of potassium-ATP channels, membrane depolarization, and enhancement of $\mathrm{Ca}^{2+}$ influx [147]. PO also boosts glycolysis and animates phosphofructokinase, lactate dehydrogenase, and pyruvate kinase enzymes [91].

$\mathrm{PO}$ lessens the chronic inflammation produced due to insulin resistance through inhibition of the Rho/ROCK/NFKB pathway, which is implicated in the production of proinflammatory molecules [148]. Moreover, $\mathrm{PO}$ can prevent DM complications by regulating lipid metabolism via phosphorylation of ACC at Ser79, which is an AMPK phosphorylation site. As a result, fatty-acid and triacylglycerol biosynthesis is inhibited, and the PI3K/Akt and AMPK pathways in skeletal muscle are improved, resulting in increased glucose uptake in adipose tissue [149]. In addition, PO is one of the richest green plant sources of phenolic acids, flavonoids, alkaloids, triterpenoids, glutathione, and other antioxidants, making it an effective antioxidant herb for DM pancreatic cell protection [150]. As a result of its phytochemical content, especially triterpenoids and homoisoflavonoids, PO can initiate the GLUT-4 translocation [151].

\subsection{Punica Granatum (PG)}

PG is an ancient perennial plant species of the Punicaceae family, which can be found in Africa, America, Europa, and Asia [152]. The roots, barks, fruits, peels, and leaves of PG are used in numerous ailments in the treatment of cancer, microbial infections, obesity, ulcer, inflammation, and Alzheimer's disease [153].

In general, there are several valuable PG phenolic constituents such as ellagic acid, punicalagin, flavonoids, anthocyanins, and flavonoids that provide high antioxidant capacity [154]. Polyphenols in PG play a significant role in its hypoglycemic effect via multiple pathways, including (i) improving the sensitivity of insulin receptors, (ii) increasing the activity of PPAR- $\gamma$ [155] and paraoxonase 1 level, which is a high-density lipoproteinassociated lipolactonase and possesses antioxidative characters [156], (iii) modulating the expression of GLUT-4 [157], and (iv) enhancing the glucose uptake by peripheral tissues and hindering gluconeogenesis [158].

Moreover, PG inhibits the dipeptidyl peptidase-4 enzyme that is linked to glucose metabolism by degrading the incretin hormones glucagon-like peptide- 1 and glucosedependent insulinotropic polypeptide, thereby stimulating insulin secretion [159]. Furthermore, PG exhibited powerful activity in reducing glucose absorption via the inhibition of pancreatic lipase and $\alpha$-amylase enzyme activities responsible for the digestion of fat and carbohydrates, respectively [160]. It was reported that PG can establish its hypoglycemic influence via inhibition of cytochrome P450 (CYP)2C9 that is responsible for the metabolization of some hypoglycemic sulfonylureas such as tolbutamide, thus increasing the efficacy of hypoglycemic drugs [161]. PG has a role in the prevention of some cardiovascular complications of DM through the suppression of lipogenesis in adipose tissue and triacylglycerol biosynthesis in the liver, as well as inhibition of fatty-acid synthase enzyme and SREBP-1c. Multiple studies have explored the antidiabetic potential of PG; one revealed the reduction in blood glucose levels and increase in insulin levels in rats by exciting $\beta$-cells and increasing their number. Another study found that, in an IDDM model 
treated with PG, hepatic lipid peroxidation was reduced and immune cell infiltration into pancreatic islets was inhibited [162].

The role of the abovementioned selected antidiabetic herbal plants is summarized in Table 1. Further in vivo studies of these plants are outlined in Table 2.

Table 1. Antidiabetic effect of medicinal plants.

\begin{tabular}{|c|c|c|c|c|}
\hline Scientific Name & Plant Family & Common Name & Traditional Use & References \\
\hline Nigella sativa & Ranunculaceae & Black cumin & $\begin{array}{l}\text { Anti-inflammatory, antidiabetic, } \\
\text { antiparasitic, and analgesic }\end{array}$ & {$[163,164]$} \\
\hline Berberis vulgaris & Berberidaceae & Berberine & $\begin{array}{l}\text { Antihyperlipidemic, anticancer, } \\
\text { anti-inflammatory, antioxidant, } \\
\text { hepatoprotective, and } \\
\text { hypoglycemic agent }\end{array}$ & {$[165,166]$} \\
\hline Curcuma longa & Zingiberaceae & Turmeric & $\begin{array}{l}\text { Anticancer, antihyperglycemic, } \\
\text { neuroprotective, antiapoptotic, } \\
\text { antimicrobial, and } \\
\text { cardioprotective }\end{array}$ & {$[167,168]$} \\
\hline Moringa oleifera & Moringaceae & Moringa & $\begin{array}{l}\text { Hypoglycemic, neuroprotective, } \\
\text { hepatoprotective, hypolipidemic, } \\
\text { and antiviral agent }\end{array}$ & {$[169,170]$} \\
\hline Portulaca oleracea & Portulacaceae & Purslane & $\begin{array}{l}\text { Anti-inflammatory, antidiabetic, } \\
\text { anticancer, analgesic, } \\
\text { immunostimulant, antimicrobial, } \\
\text { and antiviral }\end{array}$ & {$[171,172]$} \\
\hline
\end{tabular}

Table 2. Previous in vivo studies on the effect of medicinal plants on DM.

\begin{tabular}{|c|c|c|c|c|c|c|c|}
\hline \multirow{2}{*}{ Scientific Name } & \multirow{2}{*}{$\begin{array}{l}\text { Treatment } \\
\text { Form }\end{array}$} & \multirow[t]{2}{*}{ Dose } & \multicolumn{2}{|c|}{$\begin{array}{l}\text { Fasting Blood Glucose Level } \\
(\mathrm{mg} / \mathrm{dL})\end{array}$} & \multicolumn{2}{|c|}{$\underset{(\mu \mathrm{IU} / \mathrm{mL})}{\text { Fasting Insulin Level }}$} & \multirow[t]{2}{*}{ References } \\
\hline & & & Pre-Treatment & Post-Treatment & Pre- Treatment & Post- Treatment & \\
\hline Nigella sativa & Oil & $100 \mathrm{mg}$ in $10 \%$ DMSO $/ \mathrm{kg} \mathrm{Bwt} *$ & $581.31 \pm 36.31$ & $142.76 \pm 16.94$ & $101.59 \pm 5.78$ & $127.86 \pm 1.27$ & [73] \\
\hline Berberis vulgaris & $\begin{array}{l}\text { Berberine } \\
\text { chloride }\end{array}$ & $100 \mathrm{mg} / \mathrm{kg}$ Bwt & $180.1 \pm 4.38$ & $97.7 \pm 5.61$ & $20.17 \pm 2.93$ & $15.67 \pm 2.42$ & {$[97]$} \\
\hline Curcuma longa & Curcumin & $50 \mathrm{mg} / \mathrm{kg} \mathrm{Bwt}$ & $481 \pm 0.71$ & $109.20 \pm 0.86$ & $180.44 \pm 0.43$ & $80.44 \pm 0.15$ & [173] \\
\hline Moringa oleifera & $\begin{array}{l}\text { Ethanolic extract } \\
\text { of leaves }\end{array}$ & $200 \mathrm{mg} / \mathrm{kg} \mathrm{Bwt}$ & $167.0 \pm 1.96$ & $94.0 \pm 4.96$ & $45.03 \pm 13.8$ & $36.4 \pm 4.66$ & [174] \\
\hline Portulaca oleracea & Water extract & $250 \mathrm{mg} / \mathrm{kg} \mathrm{Bwt}$ & $293.2 \pm 2.4$ & $125.0 \pm 1.3$ & $18.97 \pm 0.09$ & $33.50 \pm 0.08$ & [175] \\
\hline
\end{tabular}

* Bwt: body weight.

\section{Conclusions}

The use of medicinal plant therapy for diabetes mellitus suggests its importance in the prevention and treatment of this disease. Several herbs have displayed antidiabetic activities via various mechanisms, such as attenuating oxidative stress and inflammation, increasing insulin sensitivity and glucose uptake, and regulating insulin-induced signaling in different tissues. Furthermore, various types of herbs are readily available all over the world with low cost, low toxicity, and important phytochemical contents. Nevertheless, further clinical studies are needed to confirm the valuable effects of these plant-derived preparations in treating and managing diabetes.

Author Contributions: Conceptualization, M.B.; software, M.E.-Z. and S.A.A.; validation, M.B., M.E.-Z. and S.A.A.; formal analysis, M.E.-Z.; investigation, M.B.; resources, M.E.-Z.; data curation, M.E.-Z.; writing-original draft preparation, M.E.-Z.; writing-review and editing, M.B.; visualization, S.A.A.; supervision, M.B. All authors read and agreed to the published version of the manuscript.

Funding: This review was not funded by any organization.

Institutional Review Board Statement: Not applicable.

Informed Consent Statement: Not applicable.

Data Availability Statement: Data sharing is not applicable. 
Conflicts of Interest: The authors declare no conflict of interest.

\section{References}

1. Nouraei, H.; Jahromi, M.G.; Jahromi, L.R.; Zomorodian, K.; Pakshir, K. Potential Pathogenicity of Candida Species Isolated from Oral Cavity of Patients with Diabetes Mellitus. Biomed. Res. Int. 2021, 2021, 9982744. [CrossRef]

2. Abdelalim, E.M. Modeling different types of diabetes using human pluripotent stem cells. Cell Mol. Life Sci. 2021, 78, 2459-2483. [CrossRef]

3. Altamura, S.; Mudder, K.; Schlotterer, A.; Fleming, T.; Heidenreich, E.; Qiu, R.; Hammes, H.P.; Nawroth, P.; Muckenthaler, M.U. Iron aggravates hepatic insulin resistance in the absence of inflammation in a novel $\mathrm{db} / \mathrm{db}$ mouse model with iron overload. Mol. Metab. 2021, 51, 101235. [CrossRef]

4. Aalaa, M.; Sanjari, M.; Esfahani, E.N.; Atlasi, R.; Larijani, B.; Mohajeri-Tehrani, M.R.; Mehrdad, N.; Amini, M.R. Diabetic Foot scientific activities in Endocrinology and Metabolism Research Institute. J. Diabetes Metab. Disord. 2021, 1-6. [CrossRef]

5. Wang, H.; Zhu, Z.; Wu, J.; Wang, H.; Gao, L.; Xiao, J. Effect of type II diabetes-induced osteoarthritis on articular cartilage aging in rats: A study in vivo and in vitro. Exp. Gerontol. 2021, 150, 111354. [CrossRef]

6. Srivastava, B.; Sen, S.; Bhakta, S.; Sen, K. Effect of caffeine on the possible amelioration of diabetic neuropathy: A spectroscopic study. Spectrochim. Acta A Mol. Biomol. Spectrosc. 2021, 264, 120322. [CrossRef]

7. Pal, R.; Banerjee, M. Are people with uncontrolled diabetes mellitus at high risk of reinfections with COVID-19? Prim. Care Diabetes 2021, 15, 18-20. [CrossRef]

8. Ahmed, B.; Sultana, R.; Greene, M.W. Adipose tissue and insulin resistance in obese. Biomed. Pharm. 2021, 137, 111315. [CrossRef]

9. Yang, Y.; Zhao, C.; Ye, Y.; Yu, M.; Qu, X. Prospect of Sodium-Glucose Co-transporter 2 Inhibitors Combined With Insulin for the Treatment of Type 2 Diabetes. Front. Endocrinol. 2020, 11, 190. [CrossRef]

10. Odawara, M.; Aoi, S.; Takeshima, T.; Iwasaki, K. Comparative Effects of Metformin and Dipeptidyl Peptidase-4 Inhibitors in Japanese Obese Patients with Type 2 Diabetes: A Claims Database Study. Diabetes 2021, 12, 2165-2177. [CrossRef]

11. van Gorp, A.M.; Rolfes, L.; Harmark, L.; van der Horst, P.; Hendriks, J.; Vorstenbosch, S. Insight in the safety profile of antidiabetic agents glucagon-like peptide- 1 agonists and dipeptidyl peptidase- 4 inhibitors in daily practice from the patient perspective. Pharm. Drug Saf. 2020, 29, 1588-1595.

12. Didari, E.; Sarhangi, N.; Afshari, M.; Meybodi, H.R.A.; Hasanzad, M.A. pharmacogenetic pilot study of CYP2C9 common genetic variant and sulfonylureas therapeutic response in type 2 diabetes mellitus patients. J. Diabetes Metab. Disord. 2021, 1-7. [CrossRef]

13. Rocha, R.F.; Rodrigues, T.; Menegatti, A.C.O.; Bernardes, G.J.L.; Terenzi, H. The antidiabetic drug lobeglitazone has the potential to inhibit PTP1B activity. Bioorg. Chem. 2020, 100, 103927-103923. [CrossRef] [PubMed]

14. Kathuria, D.; Raul, A.D.; Wanjari, P.; Bharatam, P.V. Biguanides: Species with versatile therapeutic applications. Eur. J. Med. Chem. 2021, 219, 113378-113417. [CrossRef] [PubMed]

15. Panigrahy, S.K.; Bhatt, R.; Kumar, A. Targeting type II diabetes with plant terpenes: The new and promising antidiabetic therapeutics. Biologia 2020, 76, 241-254. [CrossRef]

16. Mutha, R.E.; Tatiya, A.U.; Surana, S.J. Flavonoids as natural phenolic compounds and their role in therapeutics: An overview. Futur. J. Pharm. Sci. 2021, 7, 25-38. [CrossRef]

17. Jubaidi, F.F.; Zainalabidin, S.; Taib, I.S.; Hamid, Z.A.; Budin, S.B. The Potential Role of Flavonoids in Ameliorating Diabetic Cardiomyopathy via Alleviation of Cardiac Oxidative Stress, Inflammation and Apoptosis. Int. J. Mol. Sci. 2021, $22,5094$. [CrossRef]

18. Zhang, T.; Qiu, F.; Chen, L.; Liu, R.; Chang, M.; Wang, X. Identification and in vitro anti-inflammatory activity of different forms of phenolic compounds in Camellia oleifera oil. Food Chem. 2021, 344, 128660. [CrossRef]

19. Lodhi, S.; Kori, M.L. Structure-Activity Relationship and Therapeutic Benefits of Flavonoids in the Management of Diabetes and Associated Disorders. Pharm. Chem. J. 2021, 54, 1106-1125. [CrossRef]

20. Martin, M.A.; Ramos, S. Dietary Flavonoids and Insulin Signaling in Diabetes and Obesity. Cells 2021, 10, 1474. [CrossRef]

21. Saeedi, P.; Petersohn, I.; Salpea, P.; Malanda, B.; Karuranga, S.; Unwin, N.; Colagiuri, S.; Guariguata, L.; Motala, A.A.; Ogurtsova, K.; et al. Global and regional diabetes prevalence estimates for 2019 and projections for 2030 and 2045: Results from the International Diabetes Federation Diabetes Atlas, 9th edition. Diabetes Res. Clin. Pract. 2019, 157, 107843. [CrossRef] [PubMed]

22. Ramirez-Moreno, A.; Quintanar, E.M.A.; Garcia Garza, R.; Hady, K.; Melendez, V.A.; Marszalek, J.E.; Sharara-Nunez, I.; DelgadilloGuzman, D. All-trans retinoic acid improves pancreatic cell proliferation on induced type 1 diabetic rats. Fundam. Clin. Pharm. 2020, 34, 345-351. [CrossRef] [PubMed]

23. Grizzanti, J.; Corrigan, R.; Servizi, S.; Casadesus, G. Amylin signaling in diabetes and Alzheimer's disease: Therapy or pathology? J. Neurol. Neuromed. 2019, 4, 12. [CrossRef] [PubMed]

24. Ortega, M.A.; Fraile-Martínez, O.; Naya, I.; García-Honduvilla, N.; Álvarez-Mon, M.; Buján, J.; Asúnsolo, Á.; de la Torre, B. Type 2 Diabetes Mellitus Associated with Obesity (Diabesity). The Central Role of Gut Microbiota and Its Translational Applications. Nutrients 2020, 12, 2749. [CrossRef] [PubMed]

25. El-Zeftawy, M.; Ali, S.A.M.; Salah, S.; Hafez, H.S. The functional nutritional and regulatory activities of calcium supplementation from eggshell for obesity disorders management. J. Food Biochem. 2020, 44, e13313. [CrossRef]

26. Rorbach-Dolata, A.; Piwowar, A. Neurometabolic Evidence Supporting the Hypothesis of Increased Incidence of Type 3 Diabetes Mellitus in the 21st Century. Biomed. Res. Int. 2019, 2019, 1435276. [CrossRef] 
27. Jia, J.-J.; Zeng, X.-S.; Song, X.-Q.; Zhang, P.-P.; Chen, L. Diabetes mellitus and Alzheimer's disease: The protection of epigallocatechin-3-gallate in streptozotocin injection-induced models. Front. Pharmacol. 2017, 8, 834. [CrossRef]

28. Keller, A.; Varela, V.C.; Dangol, R.; Damm, P.; Heitmann, B.L.; Händel, M.N. The Role of Vitamin D in the Development of Diabetes Post Gestational Diabetes Mellitus: A Systematic Literature Review. Nutrients 2020, 12, 1733. [CrossRef]

29. Wu, L.; Nahm, C.B.; Jamieson, N.B.; Samra, J.; Clifton-Bligh, R.; Mittal, A.; Tsang, V. Risk factors for development of diabetes mellitus (Type 3c) after partial pancreatectomy: A systematic review. Clin. Endocrinol. 2020, 92, 396-406. [CrossRef]

30. Rickels, M.R. Hypoglycemia-associated autonomic failure, counterregulatory responses, and therapeutic options in type 1 diabetes. Ann. N. Y. Acad. Sci. 2019, 1454, 68-79. [CrossRef]

31. Berbudi, A.; Rahmadika, N.; Tjahjadi, A.I.; Ruslami, R. Type 2 Diabetes and its Impact on the Immune System. Curr. Diabetes Rev. 2020, 16, 442-449. [CrossRef] [PubMed]

32. Balaji, R.; Duraisamy, R.; Kumar, M.P. Complications of diabetes mellitus: A review. Drug Invent. Today 2019, 12, 98-103.

33. Jud, P.; Sourij, H. Therapeutic options to reduce advanced glycation end products in patients with diabetes mellitus: A review. Diabetes Res. Clin. Pract. 2019, 148, 54-63. [CrossRef] [PubMed]

34. Kang, G.G.; Francis, N.; Hill, R.; Waters, D.; Blanchard, C.; Santhakumar, A.B. Dietary polyphenols and gene expression in molecular pathways associated with type 2 diabetes mellitus: A Review. Int. J. Mol. Sci. 2020, 21, 140. [CrossRef] [PubMed]

35. Daryabor, G.; Atashzar, M.R.; Kabelitz, D.; Meri, S.; Kalantar, K. The effects of type 2 diabetes mellitus on organ metabolism and the immune system. Front. Immunol. 2020, 11, 1582. [CrossRef] [PubMed]

36. Cepas, V.; Collino, M.; Mayo, J.C.; Sainz, R.M. Redox Signaling and Advanced Glycation Endproducts (AGEs) in Diet-Related Diseases. Antioxidants 2020, 9, 142. [CrossRef]

37. Dariya, B.; Nagaraju, G.P. Advanced glycation end products in diabetes, cancer and phytochemical therapy. Drug Discov. Today 2020, 25, 1614-1623. [CrossRef]

38. Chen, Y.; Jiao, N.; Jiang, M.; Liu, L.; Zhu, Y.; Wu, H.; Chen, J.; Fu, Y.; Du, Q.; Xu, H. Loganin alleviates testicular damage and germ cell apoptosis induced by AGEs upon diabetes mellitus by suppressing the RAGE/p38MAPK/NF- KB pathway. J. Cell. Mol. Med. 2020, 24, 6083-6095. [CrossRef]

39. Tang, S.G.; Liu, X.Y.; Ye, J.M.; Hu, T.T.; Yang, Y.Y.; Han, T.; Tan, W. Isosteviol ameliorates diabetic cardiomyopathy in rats by inhibiting ERK and NF-kappaB signaling pathways. J. Endocrinol. 2018, 238, 47-60. [CrossRef]

40. Sharma, D.; Gondaliya, P.; Tiwari, V.; Kalia, K. Kaempferol attenuates diabetic nephropathy by inhibiting RhoA/Rho-kinase mediated inflammatory signalling. Biomed. Pharm. 2019, 109, 1610-1619. [CrossRef]

41. Abo El-Nasr, N.M.E.; Saleh, D.O.; Mahmoud, S.S.; Nofal, S.M.; Abdelsalam, R.M.; Safar, M.M.; El-Abhar, H.S. Olmesartan attenuates type 2 diabetes-associated liver injury: Cross-talk of AGE/RAGE/JNK, STAT3/SCOS3 and RAS signaling pathways. Eur. J. Pharm. 2020, 874, 173010. [CrossRef]

42. Joshi, T.; Singh, A.K.; Haratipour, P.; Sah, A.N.; Pandey, A.K.; Naseri, R.; Juyal, V.; Farzaei, M.H. Targeting AMPK signaling pathway by natural products for treatment of diabetes mellitus and its complications. J. Cell Physiol. 2019, 234, 17212-17231. [CrossRef] [PubMed]

43. Chen, M.; Huang, N.; Liu, J.; Huang, J.; Shi, J.; Jin, F. AMPK: A bridge between diabetes mellitus and Alzheimer's disease. Behav. Brain Res. 2021, 400, 113043. [CrossRef] [PubMed]

44. Szrejder, M.; Piwkowska, A. AMPK signalling: Implications for podocyte biology in diabetic nephropathy. Biol. Cell 2019, 111, 109-120. [CrossRef]

45. Shrikanth, C.B.; Nandini, C.D. AMPK in microvascular complications of diabetes and the beneficial effects of AMPK activators from plants. Phytomedicine 2020, 73, 152808. [CrossRef] [PubMed]

46. Ramadass, V.; Vaiyapuri, T.; Tergaonkar, V. Small molecule NF-kB pathway inhibitors in clinic. Int. J. Mol. Sci. 2020, 21, 5164. [CrossRef] [PubMed]

47. Wu, J.; Tao, W.; Bu, D.; Zhao, Y.; Zhang, T.; Chong, D.; Xue, B.; Xing, Z.; Li, C. Egr-1 transcriptionally activates protein phosphatase PTP1B to facilitate hyperinsulinemia-induced insulin resistance in the liver in type 2 diabetes. FEBS Lett 2019, 593, 3054-3063. [CrossRef]

48. Sun, X.; Wang, X.; Zhao, Z.; Chen, J.; Li, C.; Zhao, G. Paeoniflorin inhibited nod-like receptor protein-3 inflammasome and NF-kappaB-mediated inflammatory reactions in diabetic foot ulcer by inhibiting the chemokine receptor CXCR2. Drug Dev. Res. 2020, 82, 404-411. [CrossRef]

49. Oguntibeju, O.O. Type 2 diabetes mellitus, oxidative stress and inflammation: Examining the links. Int. J. Physiol. Pathophysiol. Pharmacol. 2019, 11, 45-63.

50. Landon, R.; Gueguen, V.; Petite, H.; Letourneur, D.; Pavon-Djavid, G.; Anagnostou, F. Impact of Astaxanthin on Diabetes Pathogenesis and Chronic Complications. Mar. Drugs 2020, 18, 357. [CrossRef]

51. Szymczak-Pajor, I.; Drzewoski, J.; Sliwinska, A. The Molecular Mechanisms by Which Vitamin D Prevents Insulin Resistance and Associated Disorders. Int. J. Mol. Sci. 2020, 21, 6644. [CrossRef]

52. Majid, M.; Masood, A.; Kadla, S.A.; Hameed, I.; Ganai, B.A. Association of Pro12Ala Polymorphism of Peroxisome ProliferatorActivated Receptor gamma 2 (PPARgamma2) Gene with Type 2 Diabetes Mellitus in Ethnic Kashmiri Population. Biochem. Genet. 2017, 55, 10-21. [CrossRef] [PubMed]

53. Yang, Q.; Vijayakumar, A.; Kahn, B.B. Metabolites as regulators of insulin sensitivity and metabolism. Nat. Rev. Mol. Cell Biol. 2018, 19, 654-672. [CrossRef] [PubMed] 
54. Mahmoud, M.; Kokozidou, M.; Auffarth, A.; Schulze-Tanzil, G. The Relationship between Diabetes Mellitus Type II and Intervertebral Disc Degeneration in Diabetic Rodent Models: A Systematic and Comprehensive Review. Cells 2020, 9, 2208. [CrossRef]

55. Tang, S.; Wang, X.; Deng, T.; Ge, H.-P.; Xiao, X.-C. Identification of C3 as a therapeutic target for diabetic nephropathy by bioinformatics analysis. Sci. Rep. 2020, 10, 1-12.

56. Jia, G.; Whaley-Connell, A.; Sowers, J.R. Diabetic cardiomyopathy: A hyperglycaemia- and insulin-resistance-induced heart disease. Diabetologia 2018, 61, 21-28. [CrossRef]

57. Grzybowski, A.; Brona, P.; Lim, G.; Ruamviboonsuk, P.; Tan, G.S.W.; Abramoff, M.; Ting, D.S.W. Artificial intelligence for diabetic retinopathy screening: A review. Eye 2019, 34, 451-460. [CrossRef] [PubMed]

58. Lauri, C.; Glaudemans, A.; Campagna, G.; Keidar, Z.; Muchnik Kurash, M.; Georga, S.; Arsos, G.; Noriega-Alvarez, E.; Argento, G.; Kwee, T.C.; et al. Comparison of White Blood Cell Scintigraphy, FDG PET/CT and MRI in Suspected Diabetic Foot Infection: Results of a Large Retrospective Multicenter Study. J. Clin. Med. 2020, 9, 1645. [CrossRef]

59. Nashawi, M.; Sheikh, O.; Battisha, A.; Ghali, A.; Chilton, R. Neural tone and cardio-renal outcomes in patients with type 2 diabetes mellitus: A review of the literature with a focus on SGLT2 inhibitors. Heart Fail. Rev. 2020, 2020 26, 643-652. [CrossRef]

60. Sözen, T.; Başaran, N.Ç.; Tinazlı, M.; Özışık, L. Musculoskeletal problems in diabetes mellitus. Eur. J. Rheumatol. 2018, 5, 258. [CrossRef]

61. Luca, M.; Di Mauro, M.; Di Mauro, M.; Luca, A. Gut Microbiota in Alzheimer's Disease, Depression, and Type 2 Diabetes Mellitus: The Role of Oxidative Stress. Oxid. Med. Cell Longev. 2019, 2019, 4730539. [CrossRef]

62. Lega, I.C.; Lipscombe, L.L. Review: Diabetes, Obesity, and Cancer-Pathophysiology and Clinical Implications. Endocr. Rev. 2020, 41, 33-52. [CrossRef]

63. Abo Baker, S.; Moawad, A. Anti-diabetic effect of Moringa oleifera extract on parotid gland of albino rats. Egypt. Dent. J. 2020, 66, 187-196. [CrossRef]

64. Reddy, P.K.; Kuchay, M.S.; Mehta, Y.; Mishra, S.K. Diabetic ketoacidosis precipitated by COVID-19: A report of two cases and review of literature. Diabetes Metab. Syndr. Clin. Res. Rev. 2020, 14, 1459-1462. [CrossRef] [PubMed]

65. Raju, B.; Santhanakumar, K.S.; Kesavachandran, U. Gastrointestinal involvement of unusual Mucormycete Syncephalastrum racemosum in a diabetic patient with adenocarcinoma: Rare case presentation with review of literature. Infection 2020, 48, 791-797. [CrossRef]

66. Hussain, A.; Bhowmik, B.; do Vale Moreira, N.C. COVID-19 and diabetes: Knowledge in progress. Diabetes Res. Clin. Pract. 2020, 162, 108142. [CrossRef] [PubMed]

67. Pal, R.; Banerjee, M.; Yadav, U.; Bhattacharjee, S. Clinical profile and outcomes in COVID-19 patients with diabetic ketoacidosis: A systematic review of literature. Diabetes Metab. Syndr. Clin. Res. Rev. 2020, 14, 1563-1569. [CrossRef]

68. Lim, S.; Bae, J.H.; Kwon, H.S.; Nauck, M.A. COVID-19 and diabetes mellitus: From pathophysiology to clinical management. Nat. Rev. Endocrinol. 2021, 17, 11-30. [CrossRef]

69. Mohebbati, R.; Abbasnezhad, A. Effects of Nigella sativa on endothelial dysfunction in diabetes mellitus: A review. J. Ethnopharmacol. 2020, 252, 112585. [CrossRef]

70. Lutterodt, H.; Luther, M.; Slavin, M.; Yin, J.-J.; Parry, J.; Gao, J.-M.; Yu, L. Fatty acid profile, thymoquinone content, oxidative stability, and antioxidant properties of cold-pressed black cumin seed oils. LWT Food Sci. Technol. 2010, 43, 1409-1413. [CrossRef]

71. Malaguarnera, G.; Cataudella, E.; Giordano, M.; Nunnari, G.; Chisari, G.; Malaguarnera, M. Toxic hepatitis in occupational exposure to solvents. World J. Gastroenterol. 2012, 18, 2756-2766. [CrossRef]

72. Balbaa, M.; Abdulmalek, S.A.; Khalil, S. Oxidative stress and expression of insulin signaling proteins in the brain of diabetic rats: Role of Nigella sativa oil and antidiabetic drugs. PLoS ONE 2017, 12, e0172429. [CrossRef]

73. Balbaa, M.; El-Zeftawy, M.; Ghareeb, D.; Taha, N.; Mandour, A.W. Nigella sativa relieves the altered insulin receptor signaling in streptozotocin-induced diabetic rats fed with a high-fat diet. Oxidative Med. Cell. Longev. 2016, 2016, 1-16. [CrossRef]

74. Shahin, Y.R.; Elguindy, N.M.; Abdel Bary, A.; Balbaa, M. The protective mechanism of Nigella sativa against diethylnitrosamineinduced hepatocellular carcinoma through its antioxidant effect and EGFR/ERK1/2 signaling. Environ. Toxicol. 2018, 33, 885-898. [CrossRef] [PubMed]

75. Kaur, G.; Invally, M.; Khan, M.K.; Jadhav, P. A nutraceutical combination of Cinnamomum cassia \&Nigella sativa for Type 1 diabetes mellitus. J. Ayurveda Integr. Med. 2018, 9, 27-37. [PubMed]

76. Hamdan, A.; Haji Idrus, R.; Mokhtar, M.H. Effects of Nigella Sativa on Type-2 Diabetes Mellitus: A Systematic Review. Int. J. Environ. Res. Public Health 2019, 16, 4911. [CrossRef]

77. Alli-oluwafuyi, A.-M.; Amin, A.; Abdulmajeed, W.I.; Imam, A.; Niyi-odumosu, F.; Abdulraheem, H.; Gwadabe, S.; Biliaminu, A.S. Nigella sativa L. oil ameliorates insulin resistance caused by dexamethasone treatment in male Wistar rats. Afr. J. Pharm. Pharmacol. 2017, 11, 144-151. [CrossRef]

78. Balbaa, M.; El-Zeftawy, M.; Abdulmalek, S.A.; Shahin, Y.R. Health-Promoting Activities of Nigella sativa Fixed Oil. In Black Cumin (Nigella sativa) Seeds: Chemistry, Technology, Functionality, and Applications; Springer: Cham, Switzerland, 2021; pp. 361-379.

79. Meddah, B.; Ducroc, R.; El Abbes Faouzi, M.; Eto, B.; Mahraoui, L.; Benhaddou-Andaloussi, A.; Martineau, L.C.; Cherrah, Y.; Haddad, P.S. Nigella sativa inhibits intestinal glucose absorption and improves glucose tolerance in rats. J. Ethnopharmacol. 2009, 121, 419-424. [CrossRef] 
80. Sobhi, W.; Stevigny, C.; Duez, P.; Calderon, B.B.; Atmani, D.; Benboubetra, M. Effect of lipid extracts of Nigella sativa L. seeds on the liver ATP reduction and alpha-glucosidase inhibition. Pak. J. Pharm. Sci. 2016, 29, 111-117.

81. Elseweidy, M.M.; Amin, R.S.; Atteia, H.H.; Aly, M.A. Nigella sativa Oil and Chromium Picolinate Ameliorate Fructose-Induced Hyperinsulinemia by Enhancing Insulin Signaling and Suppressing Insulin-Degrading Enzyme in Male Rats. Biol. Trace Elem. Res. 2018, 184, 119-126. [CrossRef]

82. Rashidmayvan, M.; Mohammadshahi, M.; Seyedian, S.S.; Haghighizadeh, M.H. The effect of Nigella sativa oil on serum levels of inflammatory markers, liver enzymes, lipid profile, insulin and fasting blood sugar in patients with non-alcoholic fatty liver. J. Diabetes Metab. Disord. 2019, 18, 453-459. [CrossRef]

83. Wu, J.; Jin, Z.; Zheng, H.; Yan, L.J. Sources and implications of NADH/NAD(+) redox imbalance in diabetes and its complications. Diabetes Metab. Syndr. Obes. 2016, 9, 145-153.

84. Karandrea, S.; Yin, H.; Liang, X.; Slitt, A.L.; Heart, E.A. Thymoquinone ameliorates diabetic phenotype in Diet-Induced Obesity mice via activation of SIRT-1-dependent pathways. PLoS ONE 2017, 12, e0185374. [CrossRef] [PubMed]

85. Kitada, M.; Koya, D. SIRT1 in Type 2 Diabetes: Mechanisms and Therapeutic Potential. Diabetes Metab. J. 2013, 37, $315-325$. [CrossRef]

86. Kooshki, A.; Tofighiyan, T.; Rastgoo, N.; Rakhshani, M.H.; Miri, M. Effect of Nigella sativa oil supplement on risk factors for cardiovascular diseases in patients with type 2 diabetes mellitus. Phytother. Res. 2020, 34, 2706-2711. [CrossRef] [PubMed]

87. Mahmoodi, M.R.; Mohammadizadeh, M. Therapeutic potentials of Nigella sativa preparations and its constituents in the management of diabetes and its complications in experimental animals and patients with diabetes mellitus: A systematic review. Complement. Med. 2020, 50, 102391. [CrossRef] [PubMed]

88. Xu, X.; Yi, H.; Wu, J.; Kuang, T.; Zhang, J.; Li, Q.; Du, H.; Xu, T.; Jiang, G.; Fan, G. Therapeutic effect of berberine on metabolic diseases: Both pharmacological data and clinical evidence. Biomed. Pharm. 2021, 133, 110984. [CrossRef] [PubMed]

89. Belwal, T.; Bisht, A.; Devkota, H.P.; Ullah, H.; Khan, H.; Pandey, A.; Bhatt, I.D.; Echeverria, J. Phytopharmacology and Clinical Updates of Berberis Species Against Diabetes and Other Metabolic Diseases. Front. Pharm. 2020, 11, 41. [CrossRef] [PubMed]

90. Liu, X.; Wang, K.; Zhou, J.; Sullivan, M.A.; Liu, Y.; Gilbert, R.G.; Deng, B. Metformin and Berberine suppress glycogenolysis by inhibiting glycogen phosphorylase and stabilizing the molecular structure of glycogen in $\mathrm{db} / \mathrm{db}$ mice. Carbohydr. Polym. 2020, 243, 116435. [CrossRef]

91. Amin, A.R.; Kassab, R.B.; Abdel Moneim, A.E.; Amin, H.K. Comparison among garlic, berberine, resveratrol, Hibiscus sabdariffa, genus Zizyphus, hesperidin, red beetroot, Catha edulis, Portulaca oleracea, and mulberry leaves in the treatment of hypertension and type 2 DM: A comprehensive review. Nat. Prod. Commun. 2020, 15, 1934578X20921623.

92. Meng, Z.; Yu, Y.; Zhang, Y.; Yang, X.; Lv, X.; Guan, F.; Hatch, G.M.; Zhang, M.; Chen, L. Highly bioavailable Berberine formulation improves Glucocorticoid Receptor-mediated Insulin Resistance via reduction in association of the Glucocorticoid Receptor with phosphatidylinositol-3-kinase. Int. J. Biol. Sci. 2020, 16, 2527-2541. [CrossRef]

93. Song, D.; Hao, J.; Fan, D. Biological properties and clinical applications of berberine. Front. Med. 2020, 14, 564-582. [CrossRef] [PubMed]

94. Wang, H.; Zhu, C.; Ying, Y.; Luo, L.; Huang, D.; Luo, Z. Metformin and berberine, two versatile drugs in treatment of common metabolic diseases. Oncotarget 2018, 9, 10135. [CrossRef] [PubMed]

95. Wu, L.; Xia, M.; Duan, Y.; Zhang, L.; Jiang, H.; Hu, X.; Yan, H.; Zhang, Y.; Gu, Y.; Shi, H.; et al. Berberine promotes the recruitment and activation of brown adipose tissue in mice and humans. Cell Death Dis. 2019, 10, 468. [CrossRef] [PubMed]

96. Ni, Y.; Xu, Z.; Li, C.; Zhu, Y.; Liu, R.; Zhang, F.; Chang, H.; Li, M.; Sheng, L.; Li, Z.; et al. Therapeutic inhibition of miR-802 protects against obesity through AMPK-mediated regulation of hepatic lipid metabolism. Theranostics 2021, 11, 1079-1099. [CrossRef] [PubMed]

97. El-Zeftawy, M.; Ghareeb, D.; ElBealy, E.R.; Saad, R.; Mahmoud, S.; Elguindy, N.; El-Kott, A.F.; El-Sayed, M. Berberine chloride ameliorated PI3K/Akt-p/SIRT-1/PTEN signaling pathway in insulin resistance syndrome induced in rats. J. Food Biochem. 2019, 43, e13049. [CrossRef]

98. Li, M.; Zhou, W.; Dang, Y.; Li, C.; Ji, G.; Zhang, L. Berberine compounds improve hyperglycemia via microbiome mediated colonic TGR5-GLP pathway in db/db mice. Biomed. Pharm. 2020, 132, 110953. [CrossRef]

99. Cui, H.X.; Hu, Y.N.; Li, J.W.; Yuan, K. Hypoglycemic Mechanism of the Berberine Organic Acid Salt under the Synergistic Effect of Intestinal Flora and Oxidative Stress. Oxid. Med. Cell Longev. 2018, 2018, 8930374. [CrossRef]

100. Ilyas, Z.; Perna, S.; Al-Thawadi, S.; Alalwan, T.A.; Riva, A.; Petrangolini, G.; Gasparri, C.; Infantino, V.; Peroni, G.; Rondanelli, M. The effect of Berberine on weight loss in order to prevent obesity: A systematic review. Biomed. Pharm. 2020, 127, 110137. [CrossRef]

101. Yue, S.J.; Liu, J.; Wang, A.T.; Meng, X.T.; Yang, Z.R.; Peng, C.; Guan, H.S.; Wang, C.Y.; Yan, D. Berberine alleviates insulin resistance by reducing peripheral branched-chain amino acids. Am. J. Physiol. Endocrinol. Metab. 2019, 316, E73-E85. [CrossRef]

102. Qin, X.; Jiang, M.; Zhao, Y.; Gong, J.; Su, H.; Yuan, F.; Fang, K.; Yuan, X.; Yu, X.; Dong, H.; et al. Berberine protects against diabetic kidney disease via promoting PGC-1alpha-regulated mitochondrial energy homeostasis. Br. J. Pharm. 2020, 177, 3646-3661. [CrossRef]

103. Liu, L.Z.; Cheung, S.C.; Lan, L.L.; Ho, S.K.; Xu, H.X.; Chan, J.C.; Tong, P.C. Berberine modulates insulin signaling transduction in insulin-resistant cells. Mol. Cell Endocrinol. 2010, 317, 148-153. [CrossRef] [PubMed] 
104. Hu, R.; Wang, M.Q.; Ni, S.H.; Wang, M.; Liu, L.Y.; You, H.Y.; Wu, X.H.; Wang, Y.J.; Lu, L.; Wei, L.B. Salidroside ameliorates endothelial inflammation and oxidative stress by regulating the AMPK/NF-kappaB/NLRP3 signaling pathway in AGEs-induced HUVECs. Eur. J. Pharm. 2020, 867, 172797. [CrossRef]

105. Calvani, M.; Subbiani, A.; Bruno, G.; Favre, C. Beta-Blockers and Berberine: A Possible Dual Approach to Contrast Neuroblastoma Growth and Progression. Oxid. Med. Cell Longev. 2020, 2020, 7534693. [CrossRef] [PubMed]

106. Li, C.; Ai, G.; Wang, Y.; Lu, Q.; Luo, C.; Tan, L.; Lin, G.; Liu, Y.; Li, Y.; Zeng, H.; et al. Oxyberberine, a novel gut microbiotamediated metabolite of berberine, possesses superior anti-colitis effect: Impact on intestinal epithelial barrier, gut microbiota profile and TLR4-MyD88-NF-kappaB pathway. Pharm. Res. 2020, 152, 104603. [CrossRef]

107. Ma, X.; Chen, Z.; Wang, L.; Wang, G.; Wang, Z.; Dong, X.; Wen, B.; Zhang, Z. The Pathogenesis of Diabetes Mellitus by Oxidative Stress and Inflammation: Its Inhibition by Berberine. Front. Pharm. 2018, 9, 782. [CrossRef]

108. Mahata, S.; Bharti, A.C.; Shukla, S.; Tyagi, A.; Husain, S.A.; Das, B.C. Berberine modulates AP-1 activity to suppress HPV transcription and downstream signaling to induce growth arrest and apoptosis in cervical cancer cells. Mol. Cancer 2011, 10, 39. [CrossRef]

109. Ashrafizadeh, M.; Fekri, H.S.; Ahmadi, Z.; Farkhondeh, T.; Samarghandian, S. Therapeutic and biological activities of berberine: The involvement of Nrf2 signaling pathway. J. Cell Biochem. 2020, 121, 1575-1585. [CrossRef] [PubMed]

110. Zych, M.; Wojnar, W.; Kielanowska, M.; Folwarczna, J.; Kaczmarczyk-Sedlak, I. Effect of Berberine on Glycation, Aldose Reductase Activity, and Oxidative Stress in the Lenses of Streptozotocin-Induced Diabetic Rats In Vivo-A Preliminary Study. Int. J. Mol. Sci. 2020, 21, 4278. [CrossRef]

111. Sharifi-Rad, J.; Rayess, Y.E.; Rizk, A.A.; Sadaka, C.; Zgheib, R.; Zam, W.; Sestito, S.; Rapposelli, S.; Neffe-Skocinska, K.; Zielinska, D.; et al. Turmeric and Its Major Compound Curcumin on Health: Bioactive Effects and Safety Profiles for Food, Pharmaceutical, Biotechnological and Medicinal Applications. Front. Pharm. 2020, 11, 01021. [CrossRef]

112. Balbaa, M.; El-Zeftawy, M.; Taha, N.; Mandour, A.W. Zinc and curcumin lower arylsulfatses and some metabolic parameters in streptozotocin-induced diabetes. J. Diabetes Metab. Disord. 2017, 16, 11. [CrossRef]

113. Ibanez, M.D.; Blazquez, M.A. Curcuma longa L. Rhizome Essential Oil from Extraction to Its Agri-Food Applications. A Review. Plants 2020, 10, 44. [CrossRef]

114. Panahi, Y.; Ahmadi, Y.; Teymouri, M.; Johnston, T.P.; Sahebkar, A. Curcumin as a potential candidate for treating hyperlipidemia: A review of cellular and metabolic mechanisms. J. Cell Physiol. 2018, 233, 141-152. [CrossRef]

115. Jin, T.R. Curcumin and dietary polyphenol research: Beyond drug discovery. Acta Pharm. Sin. 2018, 39, 779-786. [CrossRef] [PubMed]

116. Li, J.M.; Li, Y.C.; Kong, L.D.; Hu, Q.H. Curcumin inhibits hepatic protein-tyrosine phosphatase 1B and prevents hypertriglyceridemia and hepatic steatosis in fructose-fed rats. Hepatology 2010, 51, 1555-1566. [CrossRef] [PubMed]

117. Jimenez-Osorio, A.S.; Monroy, A.; Alavez, S. Curcumin and insulin resistance-Molecular targets and clinical evidences. Biofactors 2016, 42, 561-580. [CrossRef]

118. Eshaghian, A.; Khodarahmi, A.; Safari, F.; Binesh, F.; Moradi, A. Curcumin attenuates hepatic fibrosis and insulin resistance induced by bile duct ligation in rats. Br. J. Nutr. 2018, 120, 393-403. [CrossRef]

119. Wojcik, M.; Krawczyk, M.; Wojcik, P.; Cypryk, K.; Wozniak, L.A. Molecular Mechanisms Underlying Curcumin-Mediated Therapeutic Effects in Type 2 Diabetes and Cancer. Oxid Med. Cell Longev. 2018, 2018, 9698258. [CrossRef] [PubMed]

120. Xia, Z.H.; Zhang, S.Y.; Chen, Y.S.; Li, K.; Chen, W.B.; Liu, Y.Q. Curcumin anti-diabetic effect mainly correlates with its antiapoptotic actions and PI3K/Akt signal pathway regulation in the liver. Food Chem. Toxicol. 2020, 146, 111803. [CrossRef]

121. Lee, Y.S.; Cho, D.C.; Kim, C.H.; Han, I.; Gil, E.Y.; Kim, K.T. Effect of curcumin on the inflammatory reaction and functional recovery after spinal cord injury in a hyperglycemic rat model. Spine J. 2019, 19, 2025-2039. [CrossRef] [PubMed]

122. Thota, R.N.; Rosato, J.I.; Dias, C.B.; Burrows, T.L.; Martins, R.N.; Garg, M.L. Dietary Supplementation with Curcumin Reduce Circulating Levels of Glycogen Synthase Kinase-3beta and Islet Amyloid Polypeptide in Adults with High Risk of Type 2 Diabetes and Alzheimer's Disease. Nutrients 2020, 12, 1032. [CrossRef] [PubMed]

123. Abdollahi, E.; Momtazi, A.A.; Johnston, T.P.; Sahebkar, A. Therapeutic effects of curcumin in inflammatory and immune-mediated diseases: A nature-made jack-of-all-trades? J. Cell Physiol. 2018, 233, 830-848. [CrossRef] [PubMed]

124. Kuo, J.J.; Chang, H.H.; Tsai, T.H.; Lee, T.Y. Curcumin ameliorates mitochondrial dysfunction associated with inhibition of gluconeogenesis in free fatty acid-mediated hepatic lipoapoptosis. Int. J. Mol. Med. 2012, 30, 643-649. [CrossRef] [PubMed]

125. Simmons, E.C.; Scholpa, N.E.; Schnellmann, R.G. Mitochondrial biogenesis as a therapeutic target for traumatic and neurodegenerative CNS diseases. Exp. Neurol. 2020, 329, 113309. [CrossRef]

126. Lone, J.; Choi, J.H.; Kim, S.W.; Yun, J.W. Curcumin induces brown fat-like phenotype in 3T3-L1 and primary white adipocytes. J. Nutr. Biochem. 2016, 27, 193-202. [CrossRef]

127. Moulin, S.; Arnaud, C.; Bouyon, S.; Pepin, J.L.; Godin-Ribuot, D.; Belaidi, E. Curcumin prevents chronic intermittent hypoxiainduced myocardial injury. Adv. Chronic Dis. 2020, 11, 2040622320922104. [CrossRef]

128. Bahrami, A.; Atkin, S.L.; Majeed, M.; Sahebkar, A. Effects of curcumin on hypoxia-inducible factor as a new therapeutic target. Pharm. Res. 2018, 137, 159-169. [CrossRef]

129. Pu, Y.; Zhang, H.; Wang, P.; Zhao, Y.; Li, Q.; Wei, X.; Cui, Y.; Sun, J.; Shang, Q.; Liu, D.; et al. Dietary curcumin ameliorates aging-related cerebrovascular dysfunction through the AMPK/uncoupling protein 2 pathway. Cell Physiol. Biochem. 2013, 32, 1167-1177. [CrossRef] 
130. Dludla, P.V.; Nkambule, B.B.; Tiano, L.; Louw, J.; Jastroch, M.; Mazibuko-Mbeje, S.E. Uncoupling proteins as a therapeutic target to protect the diabetic heart. Pharm. Res. 2018, 137, 11-24. [CrossRef]

131. Su, J.; Zhou, X.; Wang, L.; Yin, X.; Wang, Z. Curcumin inhibits cell growth and invasion and induces apoptosis through down-regulation of Skp2 in pancreatic cancer cells. Am. J. Cancer Res. 2016, 6, 1949-1962. [PubMed]

132. Tsai, Y.C.; Kuo, P.L.; Kuo, M.C.; Hung, W.W.; Wu, L.Y.; Chang, W.A.; Wu, P.H.; Lee, S.C.; Chen, H.C.; Hsu, Y.L. The Interaction of miR-378i-Skp2 Regulates Cell Senescence in Diabetic Nephropathy. J. Clin. Med. 2018, 7, 468. [CrossRef]

133. Al-Malki, A.L.; El Rabey, H.A. The antidiabetic effect of low doses of Moringa oleifera Lam. seeds on streptozotocin induced diabetes and diabetic nephropathy in male rats. Biomed. Res. Int. 2015, 2015, 381040. [CrossRef]

134. Nova, E.; Redondo-Useros, N.; Martinez-Garcia, R.M.; Gomez-Martinez, S.; Diaz-Prieto, L.E.; Marcos, A. Potential of Moringa oleifera to Improve Glucose Control for the Prevention of Diabetes and Related Metabolic Alterations: A Systematic Review of Animal and Human Studies. Nutrients 2020, 12, 2050. [CrossRef]

135. Jaiswal, D.; Kumar Rai, P.; Kumar, A.; Mehta, S.; Watal, G. Effect of Moringa oleifera Lam. leaves aqueous extract therapy on hyperglycemic rats. J. Ethnopharmacol. 2009, 123, 392-396. [CrossRef]

136. Tshabalala, T.; Ndhlala, A.R.; Ncube, B.; Abdelgadir, H.A.; Van Staden, J. Potential substitution of the root with the leaf in the use of Moringa oleifera for antimicrobial, antidiabetic and antioxidant properties. South. Afr. J. Bot. 2020, 129, 106-112. [CrossRef]

137. Fatoumata, B.A.; MamadouSaïdou, B.A.H.; Mohamet, S.; Joseph, K.S.; Modou, M.G.; El Hadji, M.B.A. Antidiabetic properties of Moringa oleifera: A review of the literature. J. Diabetes Endocrinol. 2020, 11, 18-29. [CrossRef]

138. Ma, Z.F.; Ahmad, J.; Zhang, H.; Khan, I.; Muhammad, S. Evaluation of phytochemical and medicinal properties of Moringa (Moringa oleifera) as a potential functional food. South. Afr. J. Bot. 2020, 129, 40-46. [CrossRef]

139. Attakpa, E.S.; Sangaré, M.M.; Béhanzin, G.J.; Ategbo, J.M.; Seri, B.; Khan, N.A. Moringa olifeira Lam. stimulates activation of the insulin-dependent akt pathway. Antidiabetic effect in a diet-induced obesity (DIO) mouse model. Folia Biol. $2017,63,42$.

140. Bao, Y.; Xiao, J.; Weng, Z.; Lu, X.; Shen, X.; Wang, F. A phenolic glycoside from Moringa oleifera Lam. improves the carbohydrate and lipid metabolisms through AMPK in db/db mice. Food Chem. 2020, 311, 125948. [CrossRef]

141. Wang, F.; Bao, Y.; Shen, X.; Zengin, G.; Lyu, Y.; Xiao, J.; Weng, Z. Niazirin from Moringa oleifera Lam. attenuates high glucoseinduced oxidative stress through PKCzeta/Nox4 pathway. Phytomedicine 2019, 153066. [CrossRef]

142. Chen, G.L.; Xu, Y.B.; Wu, J.L.; Li, N.; Guo, M.Q. Hypoglycemic and hypolipidemic effects of Moringa oleifera leaves and their functional chemical constituents. Food Chem. 2020, 333, 127478. [CrossRef]

143. Kim, D.S.; Choi, M.H.; Shin, H.J. Extracts of Moringa oleifera leaves from different cultivation regions show both antioxidant and antiobesity activities. J. Food Biochem. 2020, 44, e13282. [CrossRef] [PubMed]

144. Melilli, M.G.; Pagliaro, A.; Scandurra, S.; Gentile, C.; Di Stefano, V. Omega-3 rich foods: Durum wheat spaghetti fortified with Portulaca oleracea. Food Biosci. 2020, 37, 100730. [CrossRef]

145. Nemzer, B.; Al-Taher, F.; Abshiru, N. Phytochemical composition and nutritional value of different plant parts in two cultivated and wild purslane (Portulaca oleracea L.) genotypes. Food Chem. 2020, 320, 126621. [CrossRef] [PubMed]

146. Saratale, G.D.; Saratale, R.G.; Cho, S.-K.; Ghodake, G.; Bharagava, R.N.; Park, Y.; Mulla, S.I.; Kim, D.-S.; Kadam, A.; Nair, S.; et al. Investigation of photocatalytic degradation of reactive textile dyes by Portulaca oleracea-functionalized silver nanocomposites and exploration of their antibacterial and antidiabetic potentials. J. Alloy. Compd. 2020, 833, 155083. [CrossRef]

147. Hu, Q.; Niu, Q.; Song, H.; Wei, S.; Wang, S.; Yao, L.; Li, Y.P. Polysaccharides from Portulaca oleracea L. regulated insulin secretion in INS-1 cells through voltage-gated $\mathrm{Na}(+)$ channel. Biomed. Pharm. 2019, 109, 876-885. [CrossRef] [PubMed]

148. Zheng, G.; Mo, F.; Ling, C.; Peng, H.; Gu, W.; Li, M.; Chen, Z. Portulaca oleracea L. alleviates liver injury in streptozotocin-induced diabetic mice. Drug Des. Devel 2018, 12, 47-55. [CrossRef] [PubMed]

149. Lee, J.H.; Park, J.E.; Han, J.S. Portulaca oleracea L. extract reduces hyperglycemia via PI3k/Akt and AMPK pathways in the skeletal muscles of C57BL/Ksj-db/db mice. J. Ethnopharmacol. 2020, 260, 112973. [CrossRef]

150. Chen, D.; Yao, J.-N.; Liu, T.; Zhang, H.-Y.; Li, R.-R.; Zhang, Z.-J.; Gu, X.-Z. Research and application of Portulaca oleracea in pharmaceutical area. Chin. Herb. Med. 2019, 11, 150-159. [CrossRef]

151. Park, J.E.; Park, J.Y.; Seo, Y.; Han, J.S. A new chromanone isolated from Portulaca oleracea L. increases glucose uptake by stimulating GLUT4 translocation to the plasma membrane in 3T3-L1 adipocytes. Int. J. Biol. Macromol. 2019, 123, 26-34. [CrossRef]

152. Guerrero-Solano, J.A.; Jaramillo-Morales, O.A.; Jimenez-Cabrera, T.; Urrutia-Hernandez, T.A.; Chehue-Romero, A.; OlveraHernandez, E.G.; Bautista, M. Punica protopunica Balf. the Forgotten Sister of the Common Pomegranate (Punica granatum L.): Features and Medicinal Properties-A Review. Plants 2020, 9, 1214. [CrossRef]

153. Chaves, F.M.; Pavan, I.C.B.; da Silva, L.G.S.; de Freitas, L.B.; Rostagno, M.A.; Antunes, A.E.C.; Bezerra, R.M.N.; Simabuco, F.M. Pomegranate juice and peel extracts are able to inhibit proliferation, migration and colony formation of prostate cancer cell lines and modulate the Akt/mTOR/S6K signaling pathway. Plant. Foods Hum. Nutr. 2020, 75, 54-62. [CrossRef]

154. Melgarejo-Sánchez, P.; Núñez-Gómez, D.; Martínez-Nicolás, J.J.; Hernández, F.; Legua, P.; Melgarejo, P. Pomegranate variety and pomegranate plant part, relevance from bioactive point of view: A review. Bioresour. Bioprocess. 2021, 8, 1-29. [CrossRef]

155. Jandari, S.; Hatami, E.; Ziaei, R.; Ghavami, A.; Yamchi, A.M. The effect of pomegranate (Punica granatum) supplementation on metabolic status in patients with type 2 diabetes: A systematic review and meta-analysis. Complement. Med. 2020, 52, 102478. [CrossRef] [PubMed] 
156. Estrada-Luna, D.; Martinez-Hinojosa, E.; Cancino-Diaz, J.C.; Belefant-Miller, H.; Lopez-Rodriguez, G.; Betanzos-Cabrera, G. Daily supplementation with fresh pomegranate juice increases paraoxonase 1 expression and activity in mice fed a high-fat diet. Eur. J. Nutr. 2018, 57, 383-389. [CrossRef]

157. Li, T.; Zhang, L.; Jin, C.; Xiong, Y.; Cheng, Y.Y.; Chen, K. Pomegranate flower extract bidirectionally regulates the proliferation, differentiation and apoptosis of 3T3-L1 cells through regulation of PPARgamma expression mediated by PI3K-AKT signaling pathway. Biomed. Pharm. 2020, 131, 110769. [CrossRef] [PubMed]

158. Banihani, S.A.; Fashtaky, R.A.; Makahleh, S.M.; El-Akawi, Z.J.; Khabour, O.F.; Saadeh, N.A. Effect of fresh pomegranate juice on the level of melatonin, insulin, and fasting serum glucose in healthy individuals and people with impaired fasting glucose. Food Sci. Nutr. 2020, 8, 567-574. [CrossRef]

159. Les, F.; Arbones-Mainar, J.M.; Valero, M.S.; Lopez, V. Pomegranate polyphenols and urolithin A inhibit alpha-glucosidase, dipeptidyl peptidase-4, lipase, triglyceride accumulation and adipogenesis related genes in 3T3-L1 adipocyte-like cells. J. Ethnopharmacol. 2018, 220, 67-74. [CrossRef]

160. Cano-Lamadrid, M.; Tkacz, K.; Turkiewicz, I.P.; Nowicka, P.; Hernandez, F.; Lech, K.; Carbonell-Barrachina, A.A.; Wojdylo, A. Inhibition of enzymes associated with metabolic and neurological disorder by dried pomegranate sheets as a function of pomegranate cultivar and fruit puree. J. Sci. Food Agric. 2020, 101, 2294-2303. [CrossRef] [PubMed]

161. Chakraborty, M.; Ahmed, M.G.; Bhattacharjee, A. Potential pharmacodynamic and pharmacokinetic interaction of pomegranate juice and nateglinide against diabetis induced complications in rats. Synergy 2017, 5, 1-6. [CrossRef]

162. Khajebishak, Y.; Payahoo, L.; Alivand, M.; Alipour, B. Punicic acid: A potential compound of pomegranate seed oil in Type 2 diabetes mellitus management. J. Cell. Physiol. 2019, 234, 2112-2120. [CrossRef] [PubMed]

163. Ahmad, M.F.; Ahmad, F.A.; Ashraf, S.A.; Saad, H.H.; Wahab, S.; Khan, M.I.; Ali, M.; Mohan, S.; Hakeem, K.R.; Athar, M.T. An updated knowledge of Black seed (Nigella sativa Linn.): Review of phytochemical constituents and pharmacological properties. J. Herb. Med. 2021, 25, 100404. [CrossRef]

164. Hossain, M.S.; Sharfaraz, A.; Dutta, A.; Ahsan, A.; Masud, M.A.; Ahmed, I.A.; Goh, B.H.; Urbi, Z.; Sarker, M.M.R.; Ming, L.C. A review of ethnobotany, phytochemistry, antimicrobial pharmacology and toxicology of Nigella sativa L. Biomed. Pharm. 2021, 143, 112182. [CrossRef] [PubMed]

165. Malhotra, B.; Kulkarni, G.T.; Dhiman, N.; Joshi, D.D.; Chander, S.; Kharkwal, A.; Sharma, A.K.; Kharkwal, H. Recent advances on Berberis aristata emphasizing berberine alkaloid including phytochemistry, pharmacology and drug delivery system. J. Herb. Med. 2021, 27, 100433. [CrossRef]

166. Zhang, Y.; Ma, J.; Zhang, W. Berberine for bone regeneration: Therapeutic potential and molecular mechanisms. J. Ethnopharmacol. 2021, 277, 114249. [CrossRef]

167. Abdel-Hafez, S.M.; Hathout, R.M.; Sammour, O.A. Attempts to enhance the anti-cancer activity of curcumin as a magical oncological agent using transdermal delivery. Adv. Tradit. Med. 2020, 21, 15-29. [CrossRef]

168. Quispe, C.; Cruz-Martins, N.; Manca, M.L.; Manconi, M.; Sytar, O.; Hudz, N.; Shanaida, M.; Kumar, M.; Taheri, Y.; Martorell, M.; et al. Nano-Derived Therapeutic Formulations with Curcumin in Inflammation-Related Diseases. Oxid. Med. Cell Longev. 2021, 2021, 3149223. [CrossRef]

169. Fernandes, A.; Bancessi, A.; Pinela, J.; Dias, M.I.; Liberal, A.; Calhelha, R.C.; Ciric, A.; Sokovic, M.; Catarino, L.; Ferreira, I.; et al. Nutritional and phytochemical profiles and biological activities of Moringa oleifera Lam. edible parts from Guinea-Bissau (West Africa). Food Chem. 2021, 341, 128229. [CrossRef] [PubMed]

170. Mohanty, M.; Mohanty, S.; Bhuyan, S.K.; Bhuyan, R. Phytoperspective of Moringa oleifera for oral health care: An innovative ethnomedicinal approach. Phytother. Res. 2021, 35, 1345-1357. [CrossRef]

171. Duan, Y.; Ying, Z.; He, F.; Ying, X.; Jia, L.; Yang, G. A new skeleton flavonoid and a new lignan from Portulaca oleracea L. and their activities. Fitoterapia 2021, 153, 104993. [CrossRef] [PubMed]

172. Khazdair, M.R.; Gholamnezhad, Z.; Rezaee, R.; Boskabady, M.H. Immuno-modulatory and anti-inflammatory effects of Thymus vulgaris, Zataria multiflora, and Portulaca oleracea and their constituents. Pharmacol. Res. Mod. Chin. Med. 2021, 1, 100010. [CrossRef]

173. Abdulmalek, S.; Eldala, A.; Awad, D.; Balbaa, M. Ameliorative effect of curcumin and zinc oxide nanoparticles on multiple mechanisms in obese rats with induced type 2 diabetes. Sci. Rep. 2021, 11, 20677. [CrossRef]

174. Ezzat, S.M.; El Bishbishy, M.H.; Aborehab, N.M.; Salama, M.M.; Hasheesh, A.; Motaal, A.A.; Rashad, H.; Metwally, F.M. Upregulation of MC4R and PPAR-alpha expression mediates the anti-obesity activity of Moringa oleifera Lam. in high-fat diet-induced obesity in rats. J. Ethnopharmacol. 2020, 251, 112541. [CrossRef] [PubMed]

175. Ramadan, B.K.; Schaalan, M.F.; Tolba, A.M. Hypoglycemic and pancreatic protective effects of Portulaca oleracea extract in alloxan induced diabetic rats. BMC Complement. Altern Med. 2017, 17, 37. [CrossRef] [PubMed] 